\title{
Neodymium isotope constraints on chemical weathering and past glacial activity in Svalbard
}

Jang Kwangchul 1, Bayon Germain 2, Han Yeongcheol ${ }^{1}$, Joo Young Ji 1, Kim Ji-Hoon ${ }^{3}$, Ryu Jong-Sik ${ }^{4}$, Woo Jusun ${ }^{5}$, Forwick Matthias ${ }^{6}$, Szczuciński Witold ${ }^{7}$, Kim Jung-Hyun ${ }^{1}$, Nam Seung-II ${ }^{1,}{ }^{*}$

1 Division of Polar Paleoenvironment, Korea Polar Research Institute, Incheon 21990, South Korea

2 IFREMER, Marine Geosciences Unit F-29280 Plouzané, France

3 Petroleum and Marine Resources Research Division, Korea Institute of Geoscience and Mineral Resources, Daejeon 34132, South Korea

${ }^{4}$ Department of Earth and Environmental Sciences, Pukyong National University, Busan 48513, South

Korea

${ }^{5}$ School of Earth and Environmental Sciences, Seoul National University, Seoul 08826, South Korea

6 UiT The Arctic University of Norway, Department of Geosciences, NO-9037 Tromsø, Norway

${ }^{7}$ Geohazards Lab, Institute of Geology, Adam Mickiewicz University in Poznań, 61-680 Poznań, Poland

${ }^{*}$ Corresponding author : Seung-II Nam, email address : sinam@kopri.re.kr

\begin{abstract}
:
Neodymium ( $\mathrm{Nd}$ ) isotopes in leached authigenic components of marine sediments have been increasingly used as a tracer of past ocean-water masses. Despite the general assumption that the $\mathrm{Nd}$ isotopic composition of solutes released during chemical weathering fingerprints the source rocks on continents, preferential dissolution of easily dissolvable phases may result in significant deviations in $\mathrm{Nd}$ isotopic composition between the solutes and the source rocks, with potential implications for the utility of $\mathrm{Nd}$ isotopes in paleoenvironmental studies. Here, we present the $\mathrm{Nd}$ isotopic compositions of leached and detrital fractions separated from bedrock and marine sediment samples from the Svalbard archipelago. Our goal is to further understand the behaviour of $\mathrm{Nd}$ isotopes during chemical weathering in glacial catchments and evaluate how glacier fluctuations and associated weathering congruency may have affected the export of dissolved $\mathrm{Nd}$ isotope signatures to seawater.

Our results confirm that terrestrial weathering on Svalbard causes considerable $\mathrm{Nd}$ isotopic decoupling between the leached and detrital fractions of fjord sediments $(\Delta \varepsilon N d)$, resulting from the preferential dissolution of marine precipitates in glaciated catchments dominated by sedimentary rocks. We also show that the degree of $\mathrm{Nd}$ isotopic decoupling has fluctuated in response to climate variability on Svalbard during the Holocene, which is also as suggested by the occurrence of generally higher $\Delta \varepsilon N d$ values during periods of glacier advances in sediment cores retrieved from two different fjords (Dicksonfjorden and Woodfjorden). We posit that the high $\Delta \varepsilon N d$ values can be ascribed to incongruent chemical weathering of fresh rock flour produced by glacial abrasion. This finding suggests that the degree of Nd isotopic decoupling could be used as a new proxy for tracing glacial fluctuations and associated glacier-derived nutrient inputs to the marine realm.
\end{abstract}




\section{Highlights}

- There are differences between detrital and leached $\varepsilon_{N d}(\Delta \varepsilon N d)$ in Svalbard bedrock. $\rightarrow$ The leached $\varepsilon_{N d}$ are more radiogenic than detrital $\varepsilon_{N d}$ in Svalbard fjord sediments. The $\Delta \varepsilon_{N d}$ are generally higher during the periods of glacier advances. Glacial incongruent weathering could cause higher $\Delta \varepsilon_{\mathrm{Nd}}$. $\Delta \Delta \varepsilon_{\mathrm{Nd}}$ could be a tracer for glacial fluctuation and associated nutrient inputs.

Keywords : neodymium isotopes, isotopic decoupling, incongruent weathering, glacier fluctuation, Svalbard 


\section{Introduction}

Global warming is having a profound impact on marine and terrestrial environments, and its effects are particularly evident in polar regions, where glacier and sea-ice melting in combination with associated changes in surface albedo and ocean heat distribution are key mechanisms underlying polar amplification (Taylor et al., 2013 and references therein). Glacier melting and accompanying glacial rock weathering have been recently identified as an important source of nanoparticulate nutrients available for primary production in the ocean (Hawkings et al., 2015; Wadham et al., 2019), and they potentially play an important role in marine biogeochemical cycles (review in Wadham et al., 2019). However, the impact of glacier melting on nutrient releases and marine productivity relies on sparse datasets (Hawkings et al., 2015). One important requirement for further evaluations of the future relationship among climate changes, glacial weathering (understood as chemical weathering in glacial catchments), glacier melting, and marine ecosystems is the reconstruction of past responses of glaciers to climate and subsequent changes in meltwater discharge.

Neodymium (Nd) isotopes (often expressed using the $\varepsilon_{\mathrm{Nd}}$ notation) are widely used for reconstructing past changes in ocean circulation and continental weathering fluxes (e.g., Bayon et al., 2002; Jang et al., 2017; Rutberg et al., 2000). A general consensus on the use of Nd isotopes in paleoenvironmental studies is that negligible decoupling occurs during continental weathering and sedimentary processes. However, in recent decades, multiple studies from river systems have shown that preferential dissolution of labile phases relative to more resistant minerals during weathering leads to markedly different $\mathrm{Nd}$ isotopic signatures in dissolved and solid loads (Goldstein and Jacobsen, 1987), especially in sub-Arctic regions and glacier-covered areas (Andersson et al., 2001; Hindshaw et al., 2018a; Süfke et al., 2019). This evidence for decoupling of Nd isotopes in the glacial environment suggests that past episodes of glacial retreats and advances could have possibly affected the $\varepsilon_{\mathrm{Nd}}$ signatures of the dissolved loads exported to the ocean over centennial to millennial time scales in high-latitude regions (Hindshaw et al., 2018a). For instance, an increased supply of fresh rock substrates by glacial abrasion could have led to enhanced incongruent weathering on continents (Vance et al., 2009), which would have resulted in greater $\mathrm{Nd}$ isotopic decoupling during past cold 
events because of the intrinsic Nd isotopic differences in rock-forming minerals. The importance of $\mathrm{Nd}$ isotopes in provenance studies and their utility for tracing past meltwater releases call for a better understanding of their behaviour during glacial weathering and further evaluation of how past glacial dynamics may have influenced the isotopic composition of dissolved $\mathrm{Nd}$ exported to the ocean. In this study, we present an extensive set of Nd isotopic compositions measured in both labile and detrital fractions of a series of sedimentary and metamorphic rock samples and surface sediment samples from across the Svalbard archipelago. Our aim is to characterize the effect of incongruent silicate weathering on $\mathrm{Nd}$ isotopes. Two marine sediment cores from fjords covering the Holocene period were also analyzed to assess the impact of past glacial advances and retreats on $\mathrm{Nd}$ isotopic decoupling and the preservation of $\varepsilon_{\mathrm{Nd}}$ signatures by surrounding water masses. The Svalbard archipelago is largely covered by glaciers and has diverse bedrock compositions, including sedimentary, metamorphic and volcanic rocks (Dallmann and Elvevold, 2015). Thus, the area is well suited for investigating the behaviour of $\mathrm{Nd}$ isotopes during glacial weathering.

\section{Background}

\section{1. $\quad$ Nd isotope behaviour during weathering}

Easily dissolvable components in rocks and sediments, such as marine precipitates (e.g., bioskeletal carbonates, phosphates and Fe-Mn oxides) and labile detrital minerals (e.g., volcanic components and accessory minerals) (Goldstein and Jacobsen, 1987; Hindshaw et al., 2018a), can be selectively extracted using chemical leaching methods (Bayon et al., 2002; Gutjahr et al., 2007). The comparison of radiogenic isotopic compositions between 'leachable' and residual silicate phases indicates whether isotopic decoupling may occur during continental weathering (e.g., Dausmann et al., 2019). A recent experimental investigation of Nd isotopes conducted on Svalbard (Dryadbreen and Fardalen river basins; Fig. 1) clearly showed that bedrock leachates and river waters presented more radiogenic $\mathrm{Nd}$ isotopic values (= higher $\varepsilon_{\mathrm{Nd}}$ ) than the parent bedrocks (Hindshaw et al., 2018a), suggesting that the isotopic composition of dissolved $\mathrm{Nd}$ is controlled by the preferential dissolution of labile phases during weathering. While such decoupling is mostly observed in sedimentary 
catchments (Goldstein and Jacobsen, 1987), where radiogenic labile components typically occur as marine precipitates (e.g., Hindshaw et al., 2018a), preferential dissolution of easily dissolvable accessory minerals such as apatite or titanite, can also result in decoupling in granitic catchments (e.g., Dausmann et al., 2019; Süfke et al., 2019).

On continents, the extent or magnitude of incongruent weathering is considered to be climate-dependent (Vance et al., 2009). Enhanced incongruent weathering of glacially eroded rock substrates is generally thought to have occurred during past cold periods, and they most likely resulted in an intensified release of radiogenic $\mathrm{Nd}$ and $\mathrm{Pb}$ isotopes into dissolved river loads and the marine environment. This process has been inferred in part on the basis of pronounced radiogenic $\mathrm{Pb}$ isotope excursions in various late Quaternary sediment records of dispersed Fe-Mn oxyhydroxide phases from the North Atlantic (Gutjahr et al., 2009) and high Alpine lake sediments (Süfke et al., 2019). Furthermore, Süfke et al. (2019) documented a trend towards more radiogenic authigenic Nd isotopic values in an Alpine lake sediment record, suggesting that $\mathrm{Nd}$ isotopes could also record enhanced incongruent weathering of glacially derived material in the past. Similarly, long-term variations in $\mathrm{Pb}$ and $\mathrm{Nd}$ isotopes in North Atlantic ferromanganese crusts across the onset of Northern Hemisphere glaciations have also been attributed to changes from chemical- to physical-dominated weathering regimes on surrounding continents (Gutjahr et al., 2009; von Blanckenburg and Nägler, 2001).

\subsection{Study area}

This study is based on bedrock samples from multiple onshore locations as well as sediment samples from various fjords on Spitsbergen, the largest island of the Svalbard archipelago (Fig. 1). The Svalbard archipelago is located between approximately $74-81^{\circ} \mathrm{N}$ and $10-35^{\circ} \mathrm{E}$ and surrounded by the Barents Sea and the Greenland Sea (Fig. 1). Three main water masses contribute to the hydrography of Spitsbergen fjords: (1) relatively warm and saline Atlantic Water (AW; T $>3.0$ and S $>34.65$; Cottier et al., 2005 and references therein) carried by the West Spitsbergen Current (WSC; Fig. 1), (2) cold and relatively fresh Arctic water (ArW; $-1.5<\mathrm{T}<1$ and $34.3<\mathrm{S}<34.8$; Cottier et al., 2005 and references therein) by the Sørkapp Current, an extension of the East Spitsbergen Current 
132 (ESC; Fig. 1), and (3) glacial meltwater (Cottier et al., 2005). Their mixing varies depending on

133 location within a fjord, water depth, and season of a year, resulting in complex hydrography

134 containing various water masses such as Surface Water (SW), Local Water (LW), Intermediate Water 135 (IW), Transformed Atlantic Water (TAW), and Winter Cooled Water (WCW) (e.g., Promińska et al., 136 2017; Zajączkowski et al., 2010). A top-most layer in late spring and summer is occupied by fresh $137 \mathrm{SW}(\mathrm{S}<34.00)$, which is strongly affected by glacial meltwater. $\mathrm{LW}(34.30<\mathrm{S}<34.85,-0.5<\mathrm{T}<$ 138 1.0) and WCW $(\mathrm{T}<-0.5,34.40<\mathrm{S}<35.00)$ are formed by surface cooling during autumn and brine 139 formation during winter, respectively, while TAW $(1.0<\mathrm{T}<3.0,34.65<\mathrm{S})$ and IW $(34.00<\mathrm{S}<$ $14034.65, \mathrm{~T}>1.0$ ) are formed by mixing between $\mathrm{AW}$ and $\mathrm{ArW}$, as well as various fjord masses (Cottier et al., 2005).

The bedrock geology of Svalbard in general as well as in the catchment areas of the studied fjords, is very diverse and ranges from Proterozoic metamorphic rocks to Phanerozoic sedimentary rocks (Dallmann and Elvevold, 2015) (Fig. 2). Hornsund is dominated by Proterozoic metamorphic rocks at the fjord mouth in the west to Palaeogene sedimentary rocks at the fjord head in the east. They display complicated structures, including folds, faults, and overthrusts (Dallmann and Elvevold, 2015). Similarly, the Van Mijenfjorden and Isfjorden systems display the longitudinal (W-E) variability in bedrock geology from Proterozoic metamorphic rocks to Carboniferous to Palaeogene sedimentary rocks. The catchment area of Dicksonfjorden, a northern tributary of Isfjorden, is composed of sedimentary sequences, including Devonian Old Red Sandstones and siltstones and Carboniferous-Permian carbonate-siliciclastic strata. The catchment area of Woodfjorden primarily consists of the Devonian Old Red Sandstone with a minor Quaternary volcanic complex, and Mesoproterozoic metamorphic and igneous rocks located at the heads of its tributaries (Fig. 2). The catchment of Wijdefjorden is dominated by Proterozoic to lower Silurian metamorphic rocks along the eastern shore and Upper Silurian to Devonian sedimentary rocks in the west (Dallmann and Elvevold, 2015). During the Holocene, Svalbard experienced several phases of glacier advances and retreats. 
al., 2010; Forwick and Vorren, 2009), and a warming period in western Spitsbergen lasted until 9 to 8 ka (Forwick and Vorren, 2009; Rasmussen et al., 2012). Gradual cooling accentuated by several asynchronous cooling steps (e.g., Rasmussen et al., 2012) followed this period (Forwick and Vorren, 2009). In particular, the enhanced growth and/or reformation of glaciers (Fjeldskaar et al., 2018), such as Linnébreen, Nordenskiöldbreen, Tunabreen and those in the Hajeren lake catchment occurred between 6 and 4 ka (Baeten et al., 2010; Forwick et al., 2010; Svendsen and Mangerud, 1997; van der Bilt et al., 2015). Most glaciers reached their maximum Holocene extents during the Little Ice Age (LIA) ( $\sim 66 \%$ with a total area of 38,871 km²; Martín-Moreno et al., 2017). Glaciers have been retreating since the termination of the LIA, and approximately $57 \%$ of Svalbard is currently covered with glaciers (total area of 33,775 km²; Martín-Moreno et al., 2017 and references therein).

The study focuses in particular on the analysis of two sediment cores from Dicksonfjorden and Woodfjorden. The sediment supply to Dicksonfjorden occurs mainly by glacio-fluvial runoff. On the other hand, the main sediment sources in Woodfjorden are glacio-fluvial rivers in inner Woodfjorden and Bockfjorden as well as tidewater glaciers in Liefdefjorden. At present, WCW forms by convection during the fall and winter seasons in both fjords. However, considering the known past climate and glacier variations in Svalbard during the Holocene (Baeten et al., 2010; Rasmussen et al., 2012; Svendsen and Mangerud, 1997), the oceanographic and sedimentary regime were different in the past. The relative sea level fell by up to $65 \mathrm{~m}$ on Spitsbergen during the last $12 \mathrm{ka}$ (Forman et al., 2004). The most pronounced changes occurred at the end and shortly after the deglaciation, and only minor changes have occurred since the middle Holocene.

\section{Materials and methods}

\subsection{Materials}

\subsubsection{Bedrock}

A total of 18 fresh unweathered rock samples from representative bedrock units of Svalbard were collected (Isfjorden, $\mathrm{n}=10$; Kongsfjorden, $\mathrm{n}=7$; Woodfjorden, $\mathrm{n}=1$; Table 1 and Fig. 2). Metamorphic rocks (i.e., quartzite and phyllite) were collected from the upper Proterozoic 
Generalfjella Formation in the Kongsfjorden area, while sandstone samples were collected from Isfjorden, Billefjorden and Woodfjorden. The Woodfjorden sandstone corresponds to the Devonian Old Red Sandstone, which represents the main source of sediments in Dicksonfjorden and inner Woodfjorden. Carboniferous bedrock samples from the Kongsfjorden and Isfjorden areas are mainly composed of calcareous sedimentary rocks (limestone and dolostone), while the Mesozoic bedrock samples from Isfjorden include siliciclastic mudstones, siltstones, and sandstones.

\subsubsection{Surface sediments}

A total of 45 surface (0-1 cm sediment depth) and sub-surface sediment samples (up to 5-6 cm sediment depth) (hereafter, surface sediments) from Bockfjorden $(\mathrm{n}=1)$, Dicksonfjorden $(\mathrm{n}=8)$, Hornsund $(n=21)$, Liefjefjorden $(n=1)$, Tempelfjorden $(n=1)$, Van Mijenfjorden $(n=2)$, Wijdefjorden $(n=8)$ and Woodfjorden $(n=2)($ Fig. 3$)$ were collected to characterize the modern distribution of sedimentary Nd isotopes in Spitsbergen fjords. The material was retrieved with a giant box corer $\left(50 \times 50 \times 50 \mathrm{~cm}^{3}\right)$ or a gravity corer during cruises of the $R V$ Helmer Hanssen of UiT The Arctic University of Norway in 2012, 2015, 2016, and 2017 (Supplementary Table S1). The sampling sites are located at water depths ranging from 37 to $322 \mathrm{~m}$, and they are in contact with the water masses mentioned earlier (section 2.2) depending on the fjord location, water depth and distance from the fjord mouth (e.g., Promińska et al., 2017; Zajączkowski et al., 2010).

\subsubsection{Core sediments}

Two gravity cores from Dicksonfjorden (HH16-1202-GC; $78.727^{\circ} \mathrm{N}, 15.310^{\circ} \mathrm{E}, \sim 87 \mathrm{~m}$ water depth) and Woodfjorden (HH12-964-GC; $79.651^{\circ} \mathrm{N}, 13.755^{\circ} \mathrm{E}, \sim 173 \mathrm{~m}$ water depth) were retrieved to reconstruct the evolution of sedimentary Nd isotopic compositions during the Holocene. Core HH16$1202-\mathrm{GC}$ is $\sim 274 \mathrm{~cm}$ long and spans the last $8.2 \mathrm{ka}$ (Joo et al., 2019), with an average sediment accumulation rate of $\sim 33 \mathrm{~cm} / \mathrm{ka}$. The lithology is dominated by reddish-brown mud that includes varying amounts of sandy detrital clasts. Core HH12-964-GC is $\sim 334 \mathrm{~cm}$ long and spans the last $\sim 13.3 \mathrm{ka}$ (Hansen, 2014). The average sediment accumulation rate is $25.1 \mathrm{~cm} / \mathrm{ka}$, although rates of up 
to $91 \mathrm{~cm} / \mathrm{ka}$ were calculated for the lower parts of the core. The lithology of core HH12-964-GC is dominated by silt-sized sediment, with the occurrence of coarser intervals at $\sim 110 \mathrm{~cm}$ and near the bottom of the core (Hansen, 2014). In each core, $1 \mathrm{~cm}$ thick sediment layers were collected at $10 \mathrm{~cm}$ intervals for the Nd isotope analyses ( $\mathrm{n}=28$ for HH16-1202-GC and $\mathrm{n}=35$ for HH12-964-GC).

\subsection{Analytical methods}

\subsubsection{Sample preparation}

In this study, we define 'authigenic' and 'weatherable' components as the easily dissolvable fractions (e.g., carbonate, and Fe-Mn oxyhydroxide) extracted by chemical leaching from unwashed ground bulk sediments and from bedrock, respectively (Bayon et al., 2002; Gutjahr et al., 2007; Jang et al., 2017; Rutberg et al., 2000; Werner et al., 2014). The protocol used for chemical leaching is based on the addition of $0.02 \mathrm{M}$ hydroxylamine hydrochloride in $25 \%$ acetic acid buffered to $\mathrm{pH} \sim 4$ using $\mathrm{NH}_{4} \mathrm{OH}$ (hereafter, $\mathrm{HH}$ solution) for less than 1 hour (Jang et al., 2017). The reagent-to-sample volume ratio was approximately 1 (Jang et al., 2017) to prevent the dissolution of labile detrital components (e.g., volcanic material) during the leaching process. Following the extraction of the authigenic and/or weatherable components, a second leaching step was carried out using the $\mathrm{HH}$ solution for $\sim 24$ hours to eliminate any remaining carbonate or Fe-Mn oxyhydroxide materials from the residual 'detrital' fraction (Jang et al., 2017).

After rinsing with Milli-Q water (Millipore, $>18.2 \mathrm{M} \Omega \mathrm{cm}$ ), the detrital fractions were digested by alkaline fusion for $\mathrm{Nd}$ isotopic measurements (Bayon et al., 2009). Approximately $100 \mathrm{mg}$ of dry ground detrital sediment was transferred into a glassy carbon beaker (SIGRADUR GAB 3, HTW) with $1.2 \mathrm{~g}$ of $\mathrm{Na}_{2} \mathrm{O}_{2}(>95 \%$, small beads, ACS grade, Sigma-Aldrich) and $0.6 \mathrm{~g}$ of $\mathrm{NaOH}$ ( $>98.0 \%$, pellet, ACS grade, Sigma-Aldrich) and placed in a furnace at $\sim 700^{\circ} \mathrm{C}$ for $\sim 15 \mathrm{~min}$. Neodymium and other reactive elements were then co-precipitated onto Fe oxide phases after the addition of ultrapure Milli-Q water. After centrifugation, Fe oxide precipitates were rinsed in Milli-Q water and dissolved in $2 \mathrm{M} \mathrm{HNO}_{3}$. Neodymium was purified by ion chromatography following a protocol modified from Pin and Zalduegui (1997) (Jang et al., 2017). 
3.2.2. Elemental concentration analysis

The elemental abundances (Al, K, Ca, Mg, Fe, and rare earth elements (REEs)) of wholerock samples and detrital fractions were determined by inductively coupled plasma optical emission spectrometry (ICP-OES, OPTIMA 8300, PerkinElmer) and mass spectrometry (ICP-MS, Thermo X5, Thermo Scientific) at the Korea Basic Science Institute (KBSI). Prior to the elemental analyses, the samples were dissolved by acid digestion in a PTFA digestion vessel using a 4:4:1 mixture of $\mathrm{HNO}_{3}$, $\mathrm{HF}$, and $\mathrm{HClO}_{4}$. Repeated analyses of USGS rock reference powders (BCR-2 and BHVO-2) yielded a reproducibility better than $\pm 5 \%(1 \sigma$, standard deviation $)$.

\subsubsection{Nd isotope analyses}

Neodymium isotopic measurements were performed by thermal ionization mass spectrometry (TIMS, Triton, Thermo Scientific) at the Korea Polar Research Institute. All measured ratios were corrected for mass fractionation using ${ }^{146} \mathrm{Nd} /{ }^{144} \mathrm{Nd}=0.7219$. Repeated analyses of JNdi-1 standard solutions yielded an average value of ${ }^{143} \mathrm{Nd} /{ }^{144} \mathrm{Nd}=0.512100 \pm 0.000011(2 \sigma, n=30)$, which were consistent with the reference value (0.512115) of Tanaka et al. (2000). The validity of the analytical procedure was further evaluated by analyzing the USGS reference materials BCR-2 $(0.512631 \pm 0.000013,2 \sigma, \mathrm{n}=3)$ and BHVO-1 $(0.512975 \pm 0.000009,2 \sigma, \mathrm{n}=3)$, which were also consistent with values from the literature (e.g., Raczek et al., 2003). The total procedure blank was $<0.2 \% \mathrm{Nd}$ for the detrital fractions and an order of magnitude less for the leached authigenic phases. In this study, $\mathrm{Nd}$ isotopic ratios are reported using the epsilon notation $\left(\varepsilon_{\mathrm{Nd}}\right)$, which represents the deviation of any measured ${ }^{143} \mathrm{Nd} /{ }^{144} \mathrm{Nd}$ ratio relative to the value for the modern chondritic uniform reservoir $\left(\left({ }^{143} \mathrm{Nd} /{ }^{144} \mathrm{Nd}\right)_{\mathrm{CHUR}}=0.512638 ;\right.$ Jacobsen and Wasserburg, 1980).

\section{Results}

4.1. Svalbard bedrocks 
$267(\mathrm{n}=18)$ are reported in Supplementary Table S2, Table 1, and Fig. 2. The Nd concentrations in these 268 samples vary from $\sim 0.3$ to $\sim 43 \mathrm{mg} / \mathrm{kg}$ for the bulk samples and from $\sim 0.03$ to $\sim 33 \mathrm{mg} / \mathrm{kg}$ for the

269 detrital components. Limestone, dolostone, and anhydrite are characterized by much lower $\mathrm{Nd}$ concentrations ( 0.3 to $4.0 \mathrm{mg} / \mathrm{kg}$ for bulk samples) compared with those in the siliceous sedimentary rocks, such as the Devonian Old Red Sandstone and the Permian black mudstone (up to $\sim 43 \mathrm{mg} / \mathrm{kg}$ for bulk and $\sim 35 \mathrm{mg} / \mathrm{kg}$ for the detrital component).

The detrital and weatherable fractions of the bedrocks display wide ranges of $\varepsilon_{\mathrm{Nd}}$ values, from -25.9 to 3.4 and from -25.6 to -1.2 , respectively (Fig. 2). The average values of detrital and weatherable $\varepsilon_{\mathrm{Nd}}$ are $-9.8 \pm 6.6(1 \sigma, \mathrm{n}=14)$ and $-9.8 \pm 5.7(1 \sigma, \mathrm{n}=15)$, respectively, and the two isotopic compositions are strongly correlated with each other $(r=0.82, \mathrm{n}=14)$. The Cretaceous sandstone and the mid-Jurassic to early Cretaceous shale collected close to the mouth of Isfjorden presented the minimum $\varepsilon_{\mathrm{Nd}}$ value (-25.9 for detrital and -25.6 for weatherable) and maximum $\varepsilon_{\mathrm{Nd}}$ value ( +3.4 for detrital and -1.2 for weatherable) measured in the bedrocks. Note that analyses of Ndpoor bedrocks, such as anhydrite $(<0.4 \mathrm{mg} / \mathrm{kg}$ for bulk), limestone $(<4 \mathrm{mg} / \mathrm{kg}$ for bulk) and two dolostone samples $(<1.3 \mathrm{mg} / \mathrm{kg}$ for bulk), were not possible due to insufficient intensity signals during the TIMS analysis. Except for the Cretaceous sandstone and the upper Proterozoic phyllite, the $\mathrm{Nd}$ isotopic compositions of the weatherable fractions are statistically different from the corresponding detrital fractions. Except for three Mesozoic shales, the weatherable $\varepsilon_{\mathrm{Nd}}$ signatures are systematically more radiogenic (up to 5 epsilon-units higher) than the corresponding detrital fractions (Figs. 3 \& 4).

\section{2. $\quad$ Fjord surface sediments}

The Nd concentrations of the bulk samples and their detrital components of the surface sediments show average values of 48 and $40 \mathrm{mg} / \mathrm{kg}$, respectively. Thus, they are higher than the maximum concentrations reported for the bedrock samples (see section 4.1). The $\varepsilon_{\mathrm{Nd}}$ compositions of the detrital components range from -24.9 to -10.1 (with an average of $-14.7 \pm 3.0 ; 1 \sigma, n=45$ ), while those of the authigenic components are more radiogenic, ranging from -14.5 to -9.0 (with an average 
of $-11.5 \pm 1.5 ; 1 \sigma, \mathrm{n}=45$ ) (Figs. $3 \& 4$ ). The correlation between the detrital and authigenic $\varepsilon_{\mathrm{Nd}}$ is strong $(r=0.62)$ but not as strong as that of the bedrock. Note that the sediments collected from Hornsund, with average detrital and authigenic $\varepsilon_{\mathrm{Nd}}$ values of $-15.1 \pm 3.0$ and $-10.8 \pm 1.5(1 \sigma, \mathrm{n}=21)$, respectively, display a large spatial variability reflecting the presence of various bedrock types in the surrounding catchment area, including Proterozoic metamorphic rocks and Palaeozoic, Mesozoic and Palaeogene sedimentary sequences (Dallmann and Elvevold, 2015). The sediments recovered from Dicksonfjorden are comparatively uniform in terms of $\mathrm{Nd}$ isotopes, with average detrital and authigenic $\varepsilon_{\mathrm{Nd}}$ values of $-13.6 \pm 0.1$ and $-11.5 \pm 0.2(1 \sigma, \mathrm{n}=8)$, respectively, which are very similar to the composition of the Devonian Old Red Sandstone (-13.6 \pm 0.3 and $-10.8 \pm 0.2$, respectively).

Similar detrital $\varepsilon_{\mathrm{Nd}}$ values were also obtained for sediments from Woodfjorden and its tributary fjords $(-13.6 \pm 0.5,1 \sigma, \mathrm{n}=4)$. However, the elemental ratios (e.g., $\mathrm{Fe} / \mathrm{Ca}$ and $\mathrm{Ca} / \mathrm{Al}$; Supplementary Table S3) and sediment colours are different from that in Dicksonfjorden. In Wijdefjorden, the detrital $\varepsilon_{\mathrm{Nd}}$ values of surface sediments are between those of the Devonian Old Red Sandstone (-13.6 \pm 0.3$)$ collected from the Woodfjorden catchments (Fig. 2B) and Paleoproterozoic meta-igneous rocks from Ny-Friesland ( $\varepsilon_{\mathrm{Nd}} \sim-25.4$ to -18.6 from Johansson et al., 1995) (Fig. 2A). The sediments collected in Van Mijenfjorden are characterized by less radiogenic detrital $\varepsilon_{\mathrm{Nd}}$ values of -17.3 and -16.9.

\subsection{Core sediments}

\subsubsection{Dicksonfjorden}

Sediments at site HH16-1202 in Dicksonfjorden are characterized by detrital and authigenic $\varepsilon_{\mathrm{Nd}}$ values ranging from -14.5 to -12.9 (average $-13.5 \pm 0.3,1 \sigma, \mathrm{n}=28$ ), and from -11.5 to -10.4 (average -11.2 \pm 0.2 ), respectively (Fig. 5). Compared with the bedrock and core-top sediment samples, the detrital and authigenic $\varepsilon_{\mathrm{Nd}}$ values at site HH16-1202 display only a moderate correlation over the past $7.6 \mathrm{ka}(r=0.43, \mathrm{n}=28)$. Some $\varepsilon_{\mathrm{Nd}}$ excursions can be detected in the core for both detrital and authigenic fractions (e.g., the more radiogenic value at $\sim 3.5 \mathrm{ka}$ ) as well as only for the detrital (less radiogenic $\varepsilon_{\mathrm{Nd}}$ shifts during the last millennia) or authigenic fractions (e.g., more radiogenic authigenic value at $\sim 4.5 \mathrm{ka}$ ). 


\subsubsection{Woodfjorden}

The detrital $\varepsilon_{\mathrm{Nd}}$ values at site HH12-964 in Woodfjorden fluctuated from -14.5 to -8.7 over the last $13.3 \mathrm{ka}$ (Fig. 6), whereas the authigenic fractions displayed a much narrower range of $\varepsilon_{\mathrm{Nd}}$ signatures (from -11.8 to -10.6 ; average value $-11.2 \pm 0.3,1 \sigma, \mathrm{n}=35$ ) (Fig. 6). For the detrital fractions, the average $\varepsilon_{\mathrm{Nd}}$ value of -13.4 is consistent with that of the Devonian Old Red Sandstone. Prominent peaks in the detrital $\varepsilon_{\mathrm{Nd}}$ values towards radiogenic signatures occurred at $\sim 7.2 \mathrm{ka}$ and $\sim 13.2$ ka. The overall downcore trend of authigenic values $\varepsilon_{\mathrm{Nd}}$ does not correlate with that of the detrital $\varepsilon_{\mathrm{Nd}}$ values $(r=-0.07)$, which is probably due to several outliers in the detrital $\varepsilon_{\mathrm{Nd}}$ trend.

\section{Discussion}

\subsection{Nd isotopic decoupling during incongruent terrestrial weathering in Svalbard} The weatherable components extracted from the analyzed bedrocks usually display more radiogenic $\mathrm{Nd}$ isotopic compositions than the corresponding detrital silicate fractions (Figs. $3 \& 4$ ). Enriched radiogenic Nd isotope ratios of leachates could be found, such as in volcanogenic sediments (e.g., Elmore et al., 2011). However, we are confident that the observed radiogenic $\mathrm{Nd}$ isotopic composition in the weatherable fraction does not result from the preferential dissolution of labile volcanic components due to four reasons (Supplementary Text 1). First, our mild leaching procedure would have prevented any significant detrital contamination (Jang et al., 2017). Second, if significant detrital contamination had occurred, then preferential leaching of the volcanogenic sediment in core HH12-964 should have occurred, which would have yielded pronounced radiogenic signatures in the leached authigenic fractions (which is not the case). Third, the authigenic $\varepsilon_{\mathrm{Nd}}$ signature at site HH171086 in Wijdefjorden (Fig. 1) is statistically consistent with the neighbouring seawater $\varepsilon_{\mathrm{Nd}}$ (see more detail in section 5.2.1). Finally, although the sediments collected from two proximal sites in Hornsund display similar detrital $\varepsilon_{\mathrm{Nd}}$ and major element geochemistry, they present different authigenic $\varepsilon_{\mathrm{Nd}}$ values, which is consistent with their overlying bottom water masses showing contrasting water temperatures (see more detail in section 5.2.2). 
As a consequence, the observed $\mathrm{Nd}$ isotopic decoupling between the weatherable and detrital components of Svalbard bedrocks is most likely best explained by the preferential dissolution of marine precipitates hosted by sedimentary rocks and/or labile accessory mineral phases in silicate rocks. The same hypothesis was recently proposed by Hindshaw et al. (2018a) to account for the observation that dissolved riverine loads in Svalbard were more radiogenic than corresponding suspended sediments, bedrocks, and glacial sediments (Fig. 4). In full agreement with this finding, our rock leaching experiments demonstrate that incongruent weathering in Svalbard can lead to significant Nd isotopic decoupling (Supplementary Text 2). Sedimentary rocks consist of various biogenic and authigenic components that are generally admixed with older recycled detrital minerals derived from the erosion of the basement and presumably characterized by less radiogenic $\varepsilon_{\mathrm{Nd}}$ compositions (e.g., Hindshaw et al., 2018b).

Previous studies have also reported pronounced $\mathrm{Nd}$ isotopic differences between dissolved loads and suspended sediments or bedrocks in catchments (Andersson et al., 2001; Goldstein and Jacobsen, 1987), particularly in sub-arctic river systems draining old metamorphic rocks (Andersson et al., 2001). Preferential alteration of easily dissolvable and radiogenic accessory minerals, such as apatite or titanite, is likely to occur during the weathering of igneous and metamorphic rocks (e.g., Andersson et al., 2001; von Blanckenburg and Nägler, 2001) as demonstrated by the rock leaching experiments (Dausmann et al., 2019).

In this study, significant $\mathrm{Nd}$ isotopic decoupling between detrital and weatherable fractions (>1.2 epsilon-units) was observed in one of the two metamorphic rock samples and 11 of the 12 sedimentary rock samples, with the most pronounced isotopic decoupling (about 9 epsilon-units) occurring in the Carboniferous sandstone (Figs. $3 \& 4$ ). Interestingly, the $\varepsilon_{\mathrm{Nd}}$ differences between the weatherable and detrital fractions in sedimentary rocks were not always positive and presented negative values in four samples (Figs. $3 \& 4$ ). This finding contradicts the common assumption that incongruent weathering leads to the release of more radiogenic $\mathrm{Nd}$ fractions compared to residual detrital fractions (Andersson et al., 2001; Dausmann et al., 2019; Goldstein and Jacobsen, 1987; Hindshaw et al., 2018a; von Blanckenburg and Nägler, 2001). The negative $\varepsilon_{\mathrm{Nd}}$ offsets were found in 
the Carboniferous sandstone (with a Nd isotopic difference of -9 epsilon-units) and three Mesozoic shale samples (with $\varepsilon_{\mathrm{Nd}}$ differences between -3.0 and -4.6 epsilon-units); thus, in these samples, the detrital $\varepsilon_{\mathrm{Nd}}$ values are comparatively more radiogenic than the weatherable $\varepsilon_{\mathrm{Nd}}$ values. The presence of abundant radiogenic mineral phases, such as zircon or garnet (characterized by high $\mathrm{Sm} / \mathrm{Nd}$ ratios; see Fig. 2 in Bayon et al., 2006), in silicate residual phases could account for the observed $\varepsilon_{\mathrm{Nd}}$ differences between the weatherable and detrital fractions. However, it is also likely that these negative $\varepsilon_{\mathrm{Nd}}$ differences reflect the fact that detrital fractions in sedimentary rocks may have been derived from the erosion of silicate bedrocks that are more radiogenic than associated weatherable marine precipitates.

\subsection{Origin of the authigenic $\varepsilon_{N d}$ in Svalbard fjord sediments}

\subsubsection{Terrestrial signals}

The strong Nd isotope correlation $(r=0.62)$ observed between authigenic and detrital fractions of Svalbard fjord sediments suggests that the $\varepsilon_{\mathrm{Nd}}$ signature of leached phases is mainly influenced by terrestrial inputs (Fig. 4). As reported previously, the presence of preformed Fe oxides delivered together with detrital inputs could at least partially account for these 'terrestrial' $\varepsilon_{\mathrm{Nd}}$ signatures (Bayon et al., 2004; Werner et al., 2014). Such preformed terrestrial Fe oxides can be entrained in sea-ice (Werner et al., 2014) or delivered via riverine inputs (Bayon et al., 2004). However, preformed $\mathrm{Fe}$ oxides do not account for the characteristic features of authigenic $\varepsilon_{\mathrm{Nd}}$ described in section 5.2.2.

Alternatively, glacial meltwater runoff to the fjords through glacial rivers or direct outflows from tidewater glaciers is known to deliver substantial amounts of dissolved and nanoparticulate iron (Poulton and Raiswell, 2005; Wadham et al., 2019; Wehrmann et al., 2014), and this is also the case for Svalbard, where large inputs of dissolved iron and Fe oxides can occur as a result of the glacial abrasion and subsequent dissolution of silicate rocks or iron-bearing sedimentary rocks (Hindshaw et al., 2018a; Wehrmann et al., 2014). This mechanism can be further promoted in polar regions by the photoreductive dissolution of Fe oxides trapped in ice (Kim et al., 2010). In Svalbard, this process may be linked to markedly higher contents of highly reactive Fe oxides observed in fine-grained 
glacial meltwater sediments in Finsterwalderbreen compared to other glacial and riverine sediments in the world (Poulton and Raiswell, 2005). Iron oxide in such sediments is mainly hosted by clay-bound nanoparticulate Fe oxides (10-20 nm diameter) (Poulton and Raiswell, 2005), which can be easily dissolved in seawater (Moore et al., 1979), hence representing a potential source of dissolved iron (and presumably REEs) for subsequent authigenic Fe-oxyhydroxide co-precipitation in Svalbard fjords.

Vertical benthic fluxes related to the early diagenetic iron cycle in marine sediments represent another substantial source of dissolved iron in Svalbard fjords. The diagenetic reduction of glacially derived $\mathrm{Fe}$ oxides and the subsequent release of dissolved iron into pore waters may enhance the in-situ formation of authigenic minerals in near-surface sediments, e.g., monosulphides and siderite (Görlich, 1986). This process is revealed by the high dissolved Fe concentrations (up to 800 $\mu \mathrm{M})$ determined in porewaters in Kongsfjorden and Van Keulenfjorden (Wehrmann et al., 2014) and other evidence for intense early diagenetic Fe reductions in other Svalbard fjords (e.g., Hornsund, Tempelfjorden and Van Mijenfjorden; Vandieken et al., 2006 and references therein). The reduction of Fe oxide releases abundant REEs. Therefore, the high export fluxes of dissolved Fe to Svalbard fjords are also accompanied by the delivery of substantial amounts of dissolved REEs.

\subsubsection{Seawater signals}

One seawater $\varepsilon_{\mathrm{Nd}}$ data point is available from North Svalbard Sta\#2 $\left(\varepsilon_{\mathrm{Nd}} \sim-11.8 \pm 0.4\right.$ from Andersson et al., $2008 ; 78.834^{\circ} \mathrm{N}, 9.330^{\circ} \mathrm{E}, \sim 199 \mathrm{~m}$ water depth) located only approximately $22 \mathrm{~km}$ north-north west from the core site HH17-1086 (top-core authigenic $\varepsilon_{\mathrm{Nd}} \sim-11.4 \pm 0.3$ ), i.e., the northernmost station of Wijdefjorden (Fig. 1). The two sites lie at water depths of $150 \mathrm{~m}$ and $322 \mathrm{~m}$ in comparable water masses characterized by the same density. The $\varepsilon_{\mathrm{Nd}}$ values of seawater and authigenic sediment at both sites are consistent within uncertainty, suggesting the authigenic $\varepsilon_{\mathrm{Nd}}$ as an archive of seawater $\mathrm{Nd}$ isotopic signatures (not preformed Fe oxides).

The seawater signals recorded in the authigenic $\varepsilon_{\mathrm{Nd}}$ can also be evaluated by comparing the results from two nearby sites in Hornsund; HH15-1472 and HH16-1230 (for locations see Table S2 
and Fig. 3). These two sites are located less than $2.2 \mathrm{~km}$ from each other but are separated by a sill and hence are affected by different water masses, namely, TAW (HH15-1472) and WCW (HH161230) (Promińska et al., 2017; Zajączkowski et al., 2010) (Fig. 3). The ambient bottom water masses at both sites can be clearly distinguished by different summer season temperatures, which are approximately $1^{\circ} \mathrm{C}$ in the outer fjord basin (TAW) and below $-1{ }^{\circ} \mathrm{C}$ in the inner basin (WCW) (Zajączkowski et al., 2010). The surface sediments collected at the two sites show the same detrital $\varepsilon_{\mathrm{Nd}}$ values and almost identical major elemental geochemical composition, such as $\mathrm{K} / \mathrm{Al}, \mathrm{Ca} / \mathrm{Al}, \mathrm{Fe} / \mathrm{Ca}$ and $\mathrm{Mg} / \mathrm{Al}$ ratios (Supplementary Table $\mathrm{S} 3$ ). However, the samples display different authigenic $\varepsilon_{\mathrm{Nd}}$ values (-12.1 at site HH15-1472 and -9.6 at site HH16-1230). This observation further highlights that the authigenic $\varepsilon_{\mathrm{Nd}}$ signal preserved in the surface fjord sediments in Svalbard could be derived, at least to some extent, from local water masses. (i.e., sampling sites HH16-1230, HH15-1482, and HH15-1486) are much more radiogenic than those of the regionally advected water mass within the Sørkapp Current, which is an extension of the ESC ($11.6<\varepsilon_{\mathrm{Nd}}<-10.6$ from Laukert et al., 2017; station 13; 78.834 $\mathrm{N}, 9.330^{\circ} \mathrm{E}, \sim 199 \mathrm{~m}$ water depth) (Fig. 1), suggesting strong preservation of radiogenic terrestrial inputs near the sources. Strong terrestrial signals could be partly due to efficient flocculation and, thus, the capture of small particles (including Fe oxides) and their rapid deposition in the proximal environment (Markussen et al., 2016). However, limitations exist in the simple comparison of isotopic compositions. Due to the transformation of water masses carried by ESC and mixing with Atlantic water masses within WSC on the continental shelf of western Spitsbergen, the water masses entering Hornsund fjord are a mixture of various water masses (e.g., Promińska et al., 2017). Therefore, we cannot rule out the influence of seawater inflow on the radiogenic authigenic $\varepsilon_{\mathrm{Nd}}$.

\subsection{Variation in the degree of $\mathrm{Nd}$ isotopic decoupling linked to climate-driven glacial system} changes 
systematically more radiogenic than the corresponding detrital $\varepsilon_{\mathrm{Nd}}$ signatures. Consistent with previous experimental investigations (see section 5.1), this observation further suggests that the preferential release of radiogenic $\mathrm{Nd}$ occurs during weathering in a glacial environment.

Similar observations can be drawn from the downcore records acquired from Dicksonfjorden (site HH16-1202; Supplementary Table S4) and Woodfjorden (site HH12-964; Supplementary Table S5), where the authigenic $\varepsilon_{\mathrm{Nd}}$ values are typically more radiogenic than the detrital $\varepsilon_{\mathrm{Nd}}$ values (Figs. 5 \& 6). Interestingly, the differences between the authigenic and detrital values ( $\left.\triangle \varepsilon_{\mathrm{Nd}}\right)$ at these two sites display similar variability over time (Fig. 7). Neodymium isotopic decoupling was enhanced (i.e., leading to more positive $\Delta \varepsilon_{\mathrm{Nd}}$ values) since the mid-Holocene, when new glaciers formed (Fjeldskaar et al., 2018; Svendsen and Mangerud, 1997; van der Bilt et al., 2015) (growth curve of valley glacier in Fig. 7) and/or existing glaciers on Svalbard readvanced $\sim 45$ ka (Baeten et al., 2010; Forwick et al., 2010) (growth curve of ice cap in Fig. 7). Decoupling is even more markedly enhanced during the transition period and main phase of LIA, when most glaciers on Svalbard reached their maximum extent (e.g., Martín-Moreno et al., 2017; Svendsen and Mangerud, 1997) (Fig. 7).

Based on the above discussion (section 5.2), the observed strong decoupling between authigenic and detrital signatures during the colder periods could indicate increasing contribution from (1) less radiogenic detrital materials, (2) inflow of radiogenic seawater and/or (3) more labile terrestrial sources in the glaciated catchments. The first hypothesis, although it could partly explain maximum $\triangle \varepsilon_{\mathrm{Nd}}$ values at the onset of and during parts of the LIA (Figs 5,6 , and 7) when decreased $\varepsilon_{\mathrm{Nd}}$ of detrital fractions were documented, cannot account for the significant change in the $\triangle \varepsilon_{\mathrm{Nd}}$ value during the period of glacier growth at $\sim 4.5 \mathrm{ka}$. Unfortunately, the very high diversity of rock types on Svalbard combined with the sparse dataset on the measured $\varepsilon_{\mathrm{Nd}}$ in rocks (Table 1) limits the ability to provide an exact explanation (sediment sources) for the observed temporal variability of $\varepsilon_{\mathrm{Nd}}$ in the studied sediment cores. The second hypothesis concerning the enhanced inflow of advected seawater likely cannot explain the observed changes, at least in Dicksonfjorden because of a shallow $(\sim 20 \mathrm{~m})$ sill at the fjord mouth, which has become slightly shallower in response to an isostatic rebound during the mid-Holocene (Forman et al., 2004), thereby further restricting the inflow of external water 
masses. The third hypothesis concerning the increased input of labile terrestrial materials seems to provide a good explanation of the changes, particularly those recorded in Dicksonfjorden, where the increased sediment accumulation rate $\sim 4.5 \mathrm{ka}$ (Fig. 5) indicates enhanced terrestrial inputs related to the glacio-fluvial processes at that time. The glacial activity in Dicksonfjorden likely increased at approximately $4.5 \mathrm{ka}$. This timing is synchronous with the glacier reformation in the catchment areas of Linnévatnet (5 - 4 ka from Svendsen and Mangerud, 1997) and Hajeren lakes ( 4.3 and 3.3 ka from van der Bilt et al., 2015) (Fig. 7). It also corresponded to the periods when Nordenskiöldbreen in Billefjorden (5.5 - 3.2 ka from Baeten et al., 2010) and Tunabreen in Tempelfjorden (6 - 4 ka from Forwick et al., 2010) grew (Fig. 7). Based on the evidence above, we propose that the downcore fluctuations in $\triangle \varepsilon_{\mathrm{Nd}}$ in Svalbard fjord sediments, mainly at $\sim 4.5 \mathrm{ka}$ when several catchments were likely re-occupied by glaciers, reflected changes in the degree of $\varepsilon_{\mathrm{Nd}}$ decoupling related to the presence/growth (or absence/retreat) of adjacent glaciers and associated weathering conditions. We hypothesize that the growth of glaciers provided freshly eroded rock substrates available for subglacial weathering, thereby leading to the preferential release of radiogenic Nd (e.g., Süfke et al., 2019 ) and ultimately more pronounced isotopic decoupling between authigenic and detrital $\varepsilon_{\mathrm{Nd}}$ values in the fjord sediments (Fig. 7). An increase in the $\triangle \varepsilon_{\mathrm{Nd}}$ value at site HH12-964 in mid-Woodfjorden at approximately 4.5 ka may also be attributed to the growth of tidewater glaciers draining into the Woodfjorden system (Fig. 7), which is supported by an abrupt increase in the sand content at that time (from less than 2 to $4.4 \%$; Hansen, 2014). We ruled out the potential influence of preformed Fe oxides based on the discussion in section 5.2. However, the presence of preformed phases within sediment that survived weak chemical weathering during the periods of glacier advances might partly intensify $\triangle \varepsilon_{\mathrm{Nd}}$ by increasing the authigenic $\varepsilon_{\mathrm{Nd}}$.

Our finding that $\Delta \varepsilon_{\mathrm{Nd}}$ variability in Svalbard fjord sediments may reflect weathering-induced changes in $\mathrm{Nd}$ isotopic decoupling related to glacier cover has far-reaching implications. For instance, $\triangle \varepsilon_{\mathrm{Nd}}$ could be used in future studies to reconstruct the impact of past glacial meltwater on marine productivity (e.g., Wadham et al., 2019) as a proxy to infer historical glacial releases of key nutrients (e.g., $\mathrm{P}$ and $\mathrm{Fe}$ ) associated with the dissolution of accessory phosphate minerals and nano-particulate 
iron oxides.

\section{Conclusion}

Our survey of $\mathrm{Nd}$ isotopes in leached and residual (detrital) components of Svalbard bedrock and fjord sediment samples confirms that weathering under glacial conditions is accompanied by incongruent weathering leading to significant $\mathrm{Nd}$ isotope decoupling. In Arctic environments, such as Svalbard, glacier melting provides substantial amounts of nanoparticulate Fe oxides and dissolved elements, resulting in abundant co-precipitation of hydrogenous Fe-oxyhydroxide phases in the nearby seawater/fjord environments and controlling, to a large extent, the distribution of leached authigenic $\varepsilon_{\mathrm{Nd}}$ values in fjord sediments. The difference between authigenic and detrital $\varepsilon_{\mathrm{Nd}}$ values (termed $\triangle \varepsilon_{\mathrm{Nd}}$ ) in the Holocene sedimentary records from the two fjords, Dicksonfjorden and Woodfjorden show trends that mimic the evolution of glacier activity over the last millennia, related to climate variability. The $\Delta \varepsilon_{\mathrm{Nd}}$ values and inferred $\mathrm{Nd}$ isotopic decoupling were higher during the periods of glacier advances, e.g., at $\sim 4.5 \mathrm{ka}$ and during the LIA, suggesting that increased glacier cover and concomitant glacial abrasion of fresh rock substrates resulted in intensified incongruent chemical weathering. This novel $\mathrm{Nd}$ isotope approach $\left(\triangle \varepsilon_{\mathrm{Nd}}\right)$ may be used in future studies as a new proxy for past glacial changes and associated glacial-derived nutrient inputs to the marine realm.

\section{Acknowledgments}

This study was mainly supported by the Basic Core Technology Development Program for the Oceans and the Polar Regions (NRF-2015M1A5A1037243), the Basic Science Research Program (2017R1A6A3A01076729) from the NRF funded by MSIT, South Korea, and the National Science Centre in Poland (2013/10/E/ST10/00166). We would like to thank S. D. Hur, C. Han and J. Baek for helping with the instrumental analysis and D. Kim, K. Park, Y. Ahn, Y. Joe and Y. Son for laboratory assistance. The captains and crews of R/V Helmer Hanssen supported the core sampling during the cruise. Many thanks to two anonymous reviewers for numerous constructive suggestions for improving the manuscript 


\section{References}

539 Andersson, P.S., Dahlqvist, R., Ingri, J., Gustafsson, Ö., 2001. The isotopic composition of Nd in a

540 boreal river: a reflection of selective weathering and colloidal transport. Geochim. Cosmochim. Acta $541 \quad 65,521-527$.

542 Andersson, P.S., Porcelli, D., Frank, M., Björk, G., Dahlqvist, R., Gustafsson, Ö., 2008. Neodymium 543 isotopes in seawater from the Barents Sea and Fram Strait Arctic-Atlantic gateways. Geochim. 544 Cosmochim. Acta 72, 2854-2867.

545 Baeten, N.J., Forwick, M., Vogt, C., Vorren, T.O., 2010. Late Weichselian and Holocene sedimentary 546 environments and glacial activity in Billefjorden, Svalbard. Geol. Soc. Lond., Spec. Publ. 344, 207-223.

547 Bayon, G., Barrat, J.A., Etoubleau, J., Benoit, M., Bollinger, C., Révillon, S., 2009. Determination of rare earth elements, Sc, Y, Zr, Ba, Hf and Th in geological samples by ICP-MS after Tm addition and alkaline fusion. Geostand. Geoanal. Res. 33, 51-62.

Bayon, G., German, C.R., Boella, R.M., Milton, J.A., Taylor, R.N., Nesbitt, R.W., 2002. An improved method for extracting marine sediment fractions and its application to $\mathrm{Sr}$ and $\mathrm{Nd}$ isotopic analysis. Chem. Geol. 187, 179-199. oxyhydroxides as paleoceanographic archives and the role of aeolian flux in regulating oceanic dissolved REE. Earth Planet. Sci. Lett. 224, 477-492. control of weathering processes on riverine and seawater hafnium isotope ratios. Geology 34, 433-436. Cottier, F., Tverberg, V., Inall, M., Svendsen, H., Nilsen, F., Griffiths, C., 2005. Water mass modification in an Arctic fjord through cross-shelf exchange: The seasonal hydrography of Kongsfjorden, Svalbard. J. Geophys. Res. Oceans 110.

Dallmann, W., Elvevold, S., 2015. Bedrock Geology. Geoscience Atlas of Svalbard, Norsk Polarinstitutt, 
564 for mineral-controlled release of radiogenic $\mathrm{Nd}, \mathrm{Hf}$ and $\mathrm{Pb}$ isotopes from granitic rocks during 565 progressive chemical weathering. Chem. Geol. 507, 64-84.

566 Elmore, A., Piotrowski, A., Wright, J., Scrivner, A., 2011. Testing the extraction of past seawater Nd 567 isotopic composition from North Atlantic deep sea sediments and foraminifera. Geochem. Geophys. 568 Geosyst. 12, Q09008, https://doi .org /10 .1029/2011GC003741.

569 Fjeldskaar, W., Bondevik, S., Amantov, A., 2018. Glaciers on Svalbard survived the Holocene thermal 570 optimum. Quat. Sci. Rev. 199, 18-29.

571 Forman, S., Lubinski, D., Ingólfsson, Ó., Zeeberg, J., Snyder, J., Siegert, M., Matishov, G., 2004. A 572 review of postglacial emergence on Svalbard, Franz Josef Land and Novaya Zemlya, northern Eurasia. 573 Quat. Sci. Rev. 23, 1391-1434.

574 Forwick, M., Vorren, T.O., 2009. Late Weichselian and Holocene sedimentary environments and ice 575 rafting in Isfjorden, Spitsbergen. Palaeogeogr. Palaeoclimatol. Palaeoecol. 280, 258-274.

576 Forwick, M., Vorren, T.O., Hald, M., Korsun, S., Roh, Y., Vogt, C., Yoo, K.-C., 2010. Spatial and 577 temporal influence of glaciers and rivers on the sedimentary environment in Sassenfjorden and 578 Tempelfjorden, Spitsbergen. Geol. Soc. Lond., Spec. Publ. 344, 163-193.

579 Goldstein, S.J., Jacobsen, S.B., 1987. The Nd and Sr isotopic systematics of river-water dissolved 580 material: Implications for the sources of $\mathrm{Nd}$ and $\mathrm{Sr}$ in seawater. Chem. Geol. 66, 245-272.

581 Görlich, K., 1986. Glacimarine sedimentation of muds in Hornsund fjord, Spitsbergen. Ann. Soc. Geol. Pol. 56, 433-477.

583 Gutjahr, M., Frank, M., Halliday, A.N., Keigwin, L.D., 2009. Retreat of the Laurentide ice sheet tracked 584 by the isotopic composition of $\mathrm{Pb}$ in western North Atlantic seawater during termination 1. Earth Planet. 585 Sci. Lett. 286, 546-555.

586 Gutjahr, M., Frank, M., Stirling, C.H., Klemm, V., van de Flierdt, T., Halliday, A.N., 2007. Reliable 587 extraction of a deepwater trace metal isotope signal from Fe-Mn oxyhydroxide coatings of marine 588 sediments. Chem. Geol. 242, 351-370. Hansen, T., 2014. Late Weichselian and Holocene sedimentary processes and glacier dynamics in 590 Woodfjorden, Bockfjorden and Liefdefjorden, North Spitsbergen. The Arctic University of Norway. 
591 Hawkings, J., Wadham, J., Tranter, M., Lawson, E., Sole, A., Cowton, T., Tedstone, A., Bartholomew,

592 I., Nienow, P., Chandler, D., 2015. The effect of warming climate on nutrient and solute export from the 593 Greenland Ice Sheet. Geochem. Perspect. Lett 1, 94-104.

594 Hindshaw, R.S., Aciego, S.M., Piotrowski, A.M., Tipper, E.T., 2018a. Decoupling of dissolved and 595 bedrock neodymium isotopes during sedimentary cycling. Geochem. Perspect. Lett. 8, 43-46.

596 Hindshaw, R.S., Tosca, N.J., Piotrowski, A.M., Tipper, E.T., 2018b. Clay mineralogy, strontium and 597 neodymium isotope ratios in the sediments of two High Arctic catchments (Svalbard). Earth Surf. 598 Dynam. 6, 141-161.

599 Jacobsen, S.B., Wasserburg, G.J., 1980. Sm-Nd isotopic evolution of chondrites. Earth Planet. Sci. Lett. $600 \quad 50,139-155$.

601 Jang, K., Huh, Y., Han, Y., 2017. Authigenic Nd isotope record of North Pacific Intermediate Water 602 formation and boundary exchange on the Bering Slope. Quat. Sci. Rev. 156, 150-163. Johansson, Å., Gee, D., Björklund, L., Witt-Nilsson, P., 1995. Isotope studies of granitoids from the Bangenhuk formation, Ny Friesland Caledonides, Svalbard. Geol. Mag. 132, 303-320. Joo, Y.J., Forwick, M., Park, K., Joe, Y., Son, Y.J., Nam, S.-I., 2019. Holocene environmental changes in Dicksonfjorden, west Spitsbergen, Svalbard. Polar Res. 38, 3426, https://doi .org /10 .33265 /polar.v38 .3426.

Kim, K., Choi, W., Hoffmann, M.R., Yoon, H.-I., Park, B.-K., 2010. Photoreductive dissolution of iron oxides trapped in ice and its environmental implications. Environ. Sci. Technol. 44, 4142-4148.

610 Laukert, G., Frank, M., Bauch, D., Hathorne, E.C., Rabe, B., von Appen, W.-J., Wegner, C., Zieringer, M., Kassens, H., 2017. Ocean circulation and freshwater pathways in the Arctic Mediterranean based on a combined Nd isotope, REE and oxygen isotope section across Fram Strait. Geochim. Cosmochim. Acta 202, 285-309. Markussen, T.N., Elberling, B., Winter, C., Andersen, T.J., 2016. Flocculated meltwater particles control Arctic land-sea fluxes of labile iron. Sci. Rep.-UK 6, 24033, https://doi .org /10 .1038 /srep24033.

617 Martín-Moreno, R., Allende Álvarez, F., Hagen, J.O., 2017. 'Little Ice Age' glacier extent and 
subsequent retreat in Svalbard archipelago. The Holocene 27, 1379-1390.

Moore, R., Burton, J., Williams, P.L., Young, M., 1979. The behaviour of dissolved organic material, iron and manganese in estuarine mixing. Geochim. Cosmochim. Acta 43, 919-926.

Pin, C., Zalduegui, J.S., 1997. Sequential separation of light rare-earth elements, thorium and uranium by miniaturized extraction chromatography: Application to isotopic analyses of silicate rocks. Anal. Chim. Acta 339, 79-89.

Poulton, S.W., Raiswell, R., 2005. Chemical and physical characteristics of iron oxides in riverine and glacial meltwater sediments. Chem. Geol. 218, 203-221.

Promińska, A., Cisek, M., Walczowski, W., 2017. Kongsfjorden and Hornsund hydrography comparative study based on a multiyear survey in fjords of west Spitsbergen. Oceanologia 59, 397-412. Raczek, I., Jochum, K.P., Hofmann, A.W., 2003. Neodymium and strontium isotope data for USGS reference materials BCR-1, BCR-2, BHVO-1, BHVO-2, AGV-1, AGV-2, GSP-1, GSP-2 and eight MPI-DING reference glasses. Geostandard. Newslett. 27, 173-179.

Rasmussen, T.L., Forwick, M., Mackensen, A., 2012. Reconstruction of inflow of Atlantic Water to Isfjorden, Svalbard during the Holocene: Correlation to climate and seasonality. Mar. Micropaleontol. 94, 80-90.

Rutberg, R.L., Hemming, S.R., Goldstein, S.L., 2000. Reduced North Atlantic Deep Water flux to the glacial Southern Ocean inferred from neodymium isotope ratios. Nature 405, 935-938.

Süfke, F., Gutjahr, M., Gilli, A., Anselmetti, F.S., Glur, L., Eisenhauer, A., 2019. Early stage weathering systematics of $\mathrm{Pb}$ and $\mathrm{Nd}$ isotopes derived from a high-Alpine Holocene lake sediment record. Chem. Geol. 507, 42-53.

Svendsen, J.I., Mangerud, J., 1997. Holocene glacial and climatic variations on Spitsbergen, Svalbard. The Holocene 7, 45-57.

Tanaka, T., Togashi, S., Kamioka, H., Amakawa, H., Kagami, H., Hamamoto, T., Yuhara, M., Orihashi, Y., Yoneda, S., Shimizu, H., Kunimaru, T., Takahashi, K., Yanagi, T., Nakano, T., Fujimaki, H., Shinjo, R., Asahara, Y., Tanimizu, M., Dragusanu, C., 2000. JNdi-1: a neodymium isotopic reference in consistency with LaJolla neodymium. Chem. Geol. 168, 279-281. 
645 Taylor, P.C., Cai, M., Hu, A., Meehl, J., Washington, W., Zhang, G.J., 2013. A decomposition of

646 feedback contributions to polar warming amplification. J. Climate 26, 7023-7043.

647 van der Bilt, W.G.M., Bakke, J., Vasskog, K., D'Andrea, W.J., Bradley, R.S., Ólafsdóttir, S., 2015.

648 Reconstruction of glacier variability from lake sediments reveals dynamic Holocene climate in Svalbard.

649 Quat. Sci. Rev. 126, 201-218.

650 Vance, D., Teagle, D.A., Foster, G.L., 2009. Variable Quaternary chemical weathering fluxes and

651 imbalances in marine geochemical budgets. Nature 458, 493-496.

652 Vandieken, V., Finke, N., Jørgensen, B.B., 2006. Pathways of carbon oxidation in an Arctic fjord 653 sediment (Svalbard) and isolation of psychrophilic and psychrotolerant Fe(III)-reducing bacteria. Mar.

654 Ecol. Prog. Ser. 322, 29-41.

655 von Blanckenburg, F., Nägler, T.F., 2001. Weathering versus circulation-controlled changes in 656 radiogenic isotope tracer composition of the Labrador Sea and North Atlantic Deep Water. 657 Paleoceanography $16,424-434$.

658 Wadham, J.L., Hawkings, J.R., Tarasov, L., Gregoire, L.J., Spencer, R.G.M., Gutjahr, M., Ridgwell, A., 659 Kohfeld, K.E., 2019. Ice sheets matter for the global carbon cycle. Nat. Commun. 10, 3567.

660 Wehrmann, L.M., Formolo, M.J., Owens, J.D., Raiswell, R., Ferdelman, T.G., Riedinger, N., Lyons, 661 T.W., 2014. Iron and manganese speciation and cycling in glacially influenced high-latitude fjord sediments (West Spitsbergen, Svalbard): Evidence for a benthic recycling-transport mechanism. Geochim. Cosmochim. Acta 141, 628-655.

Werner, K., Frank, M., Teschner, C., Müller, J., Spielhagen, R.F., 2014. Neoglacial change in deep water exchange and increase of sea-ice transport through eastern Fram Strait: evidence from radiogenic isotopes. Quat. Sci. Rev. 92, 190-207.

667

Zajączkowski, M., Szczuciński, W., Plessen, B., Jernas, P., 2010. Benthic foraminifera in Hornsund, 668 Svalbard: Implications for paleoenvironmental reconstructions. Pol. Polar Res. 31, 349-375. 
670

671

672

673

674

675

676

677

678

679

680

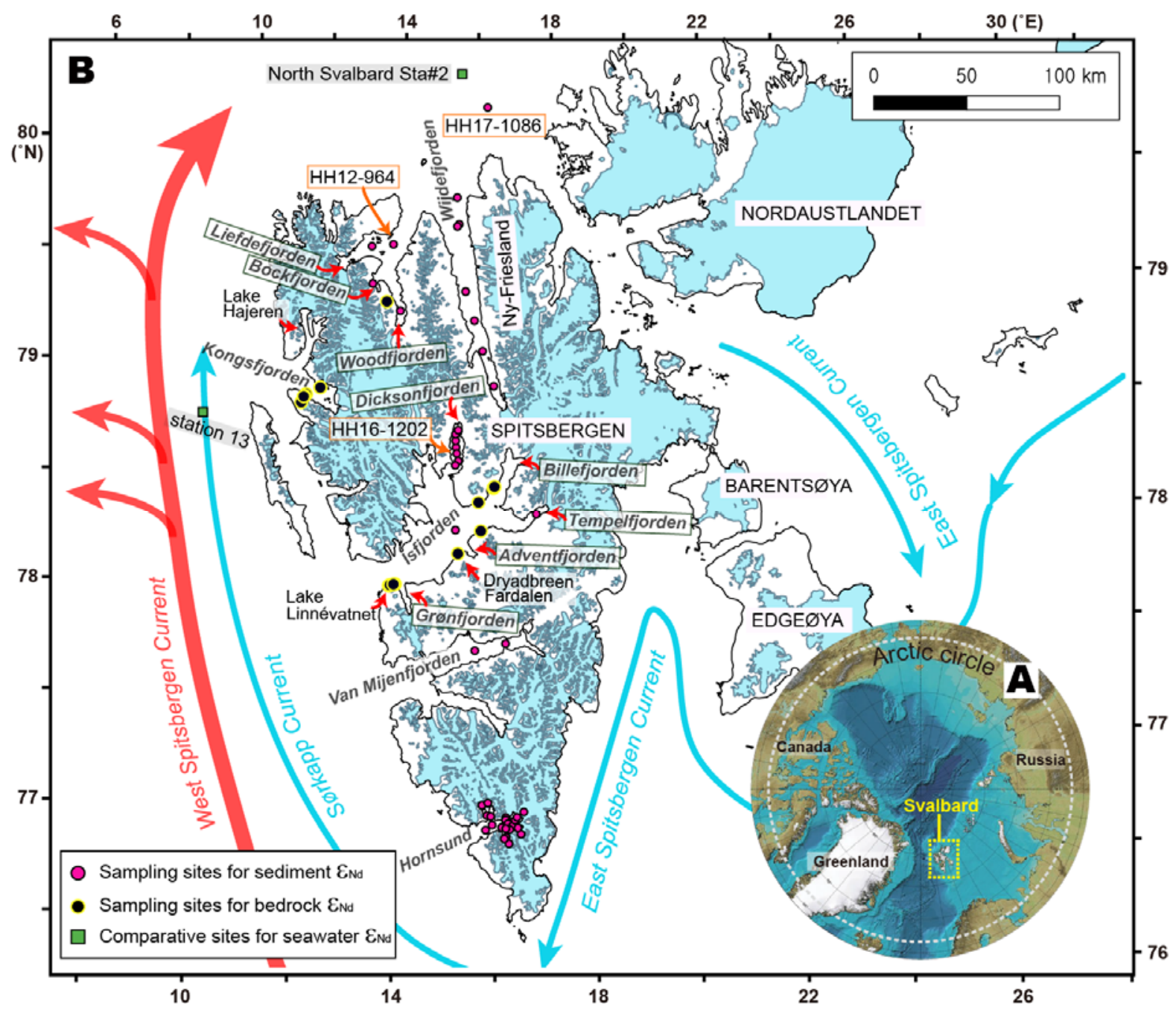

Figure 1. (A) Map of the Arctic showing the location of the Svalbard archipelago. (B) Map of the Svalbard archipelago. Locations of bedrock and fjord-sediments sample as well as place names mentioned in the text are indicated. Sky blue land areas represent the glacier coverage at present. Red and sky blue arrows indicate the West Spitsbergen Current (WSC) and the Sørkapp Current (branch of the East Spitsbergen Current (ESC)), respectively. The comparative sites (North Svalbard Sta\#2 and station 13) for the $\varepsilon_{\mathrm{Nd}}$ values of Atlantic Water and Arctic Water inflows carried by the WSC and the ESC, respectively, are also shown. See Table S1 for the coordinates of the sampling and comparative sites. 

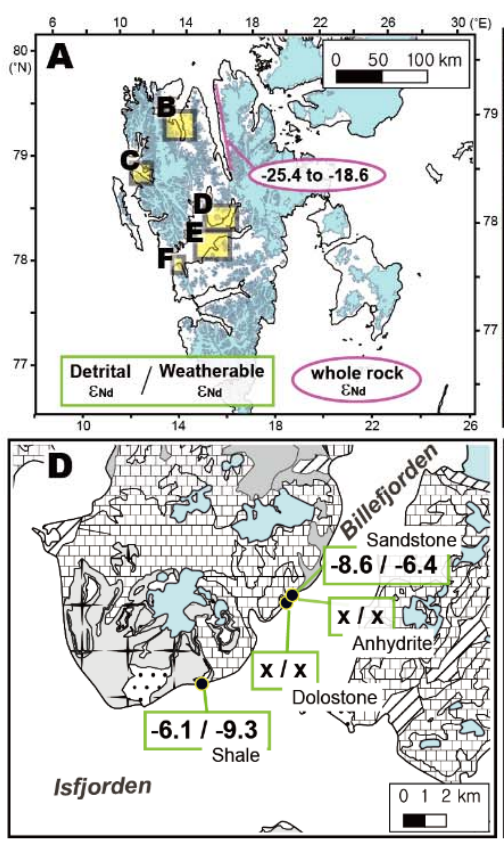
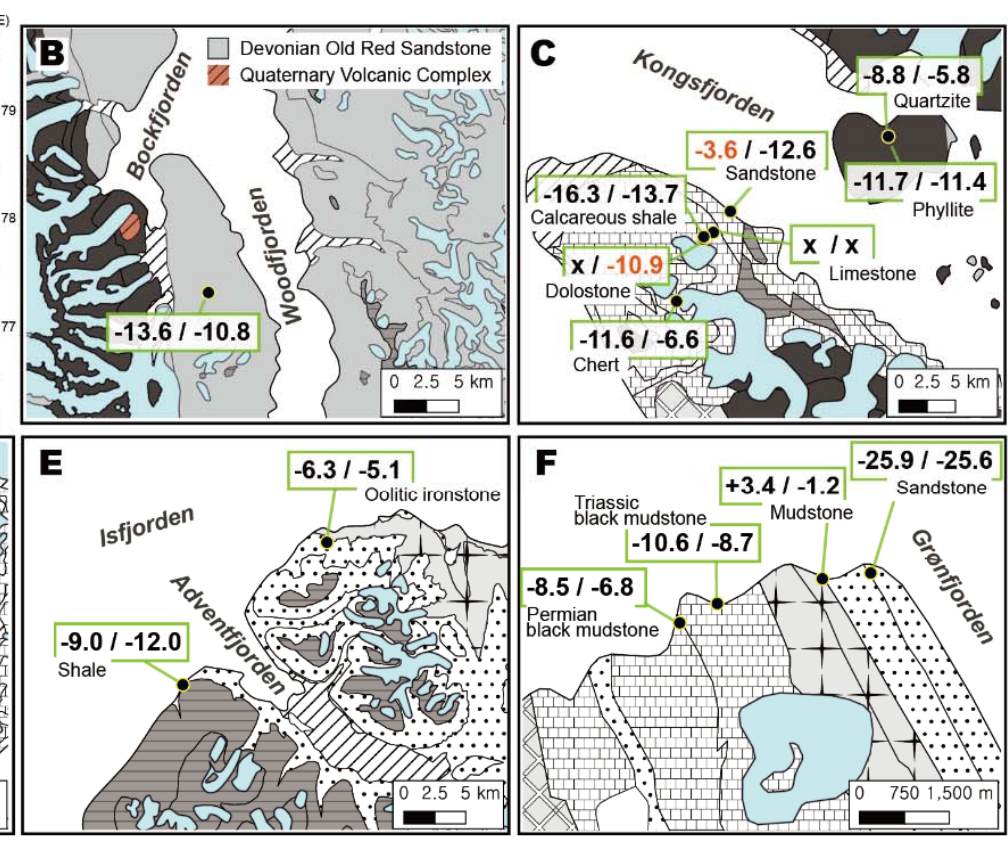

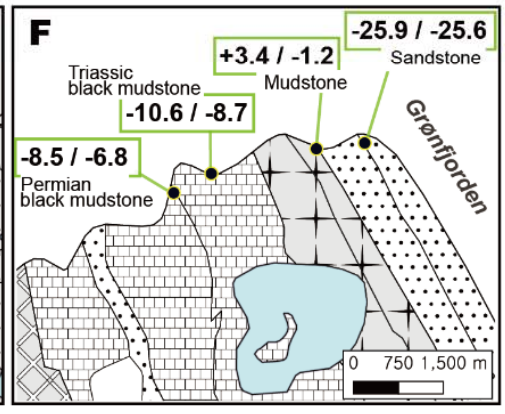

\begin{tabular}{|c|c|c|c|c|c|c|}
\hline Bedrock ages & $Q 7$ & Quaternary & $\begin{array}{l}\text { Neogene } \\
\text { and Paleogene }\end{array}$ & $\because \because{ }^{\text {upper Jurassic }}$ & + & $\begin{array}{l}\text { Triassic and } \\
\text { lowermost Jurassic }\end{array}$ \\
\hline $\begin{array}{l}\text { Carboniferous } \\
\text { and Permian }\end{array}$ & & $\begin{array}{l}\text { Devonian and } \\
\text { uppermost Silurian }\end{array}$ & $\begin{array}{l}\text { Cambrian, Ordovician } \\
\text { and lower Silurian }\end{array}$ & Neoproterozoic & & $\begin{array}{l}\text { Paleoproterozoic } \\
\text { and Mesoproterozoic }\end{array}$ \\
\hline
\end{tabular}

Figure 2. (A) Map of Svalbard showing the sampling locations (B) to (F) for the bedrock. The $\varepsilon_{\mathrm{Nd}}$ values of detrital and weatherable components in the catchment areas of Woodfjorden (B), Kongsfjorden (C) and Isfjorden and its tributary Billefjorden (D, E, and F) are marked with green rectangles. Samples with too little $\mathrm{Nd}$ to obtain data are marked with an ' $\mathrm{x}$ '. $\varepsilon_{\mathrm{Nd}}$ values with high uncertainties ( $>0.5$ epsilon-unit) are in red numbers. The bedrock samples include sixteen sedimentary rocks and two metamorphic rocks. Various bedrock ages are marked with different symbols. For comparison, the $\varepsilon_{\mathrm{Nd}}$ value measured from whole rocks in Ny-Friesland (for location see Fig. 1) is also marked with pink ellipses in Fig 2A (data from Johansson et al., 1995). The geologic map is modified after Dallmann and Elvevold (2015). 

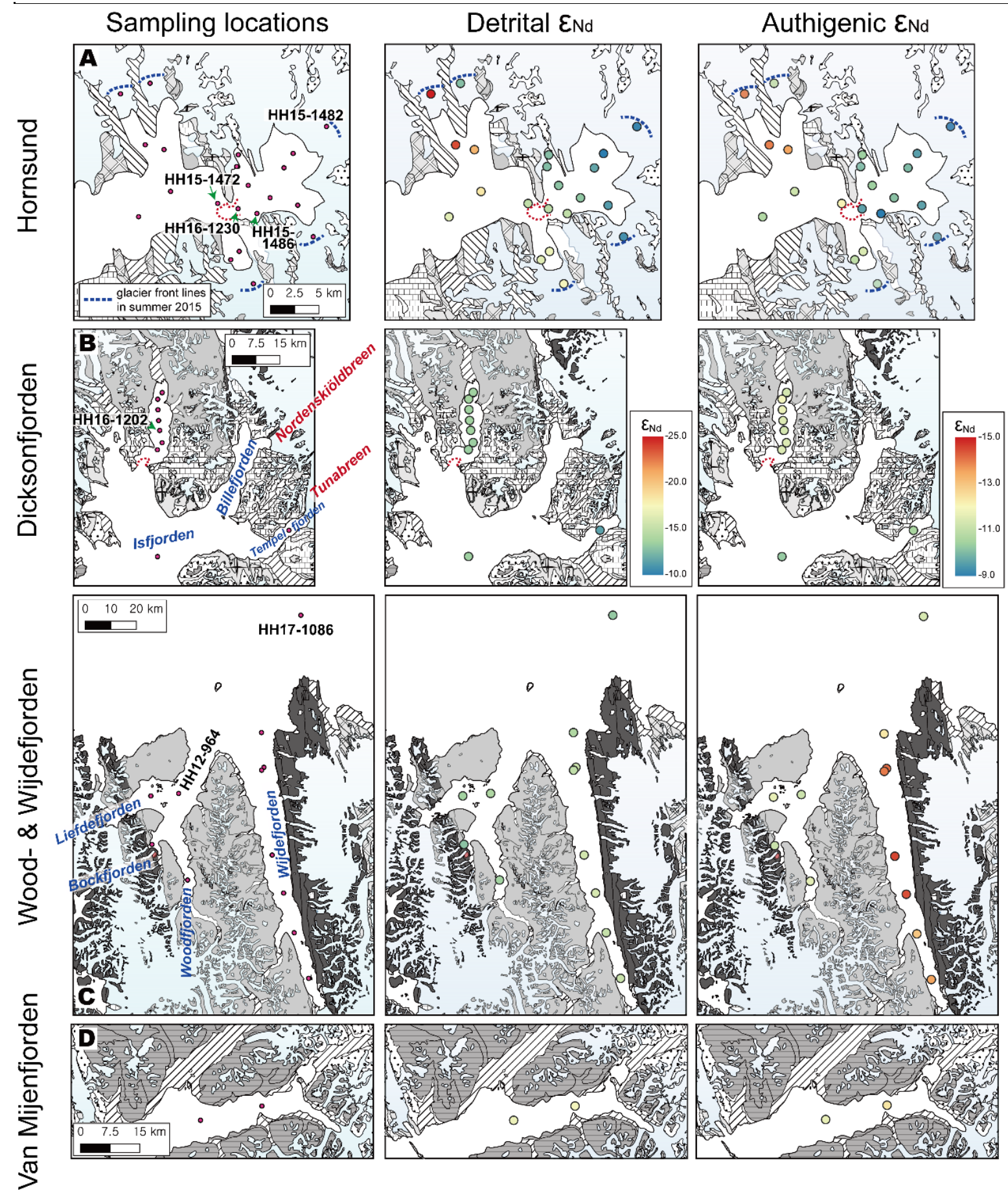

Figure 3. Maps of the locations of fjord sediments (left column). $\varepsilon_{\mathrm{Nd}}$ of detrital (central column) and authigenic (right column) components within surface sediments collected from (A) Hornsund, (B) Dicksonfjorden, Isfjorden, Tempelfjorden, (C) Woodfjorden, Wijdefjorden, and (D) Van Mijenfjorden. The present glacier fronts in Hornsund (summer 2015) are indicated by blue dashed lines, and major sills in Hornsund and Dicksonfjorden are marked by red dotted lines. 


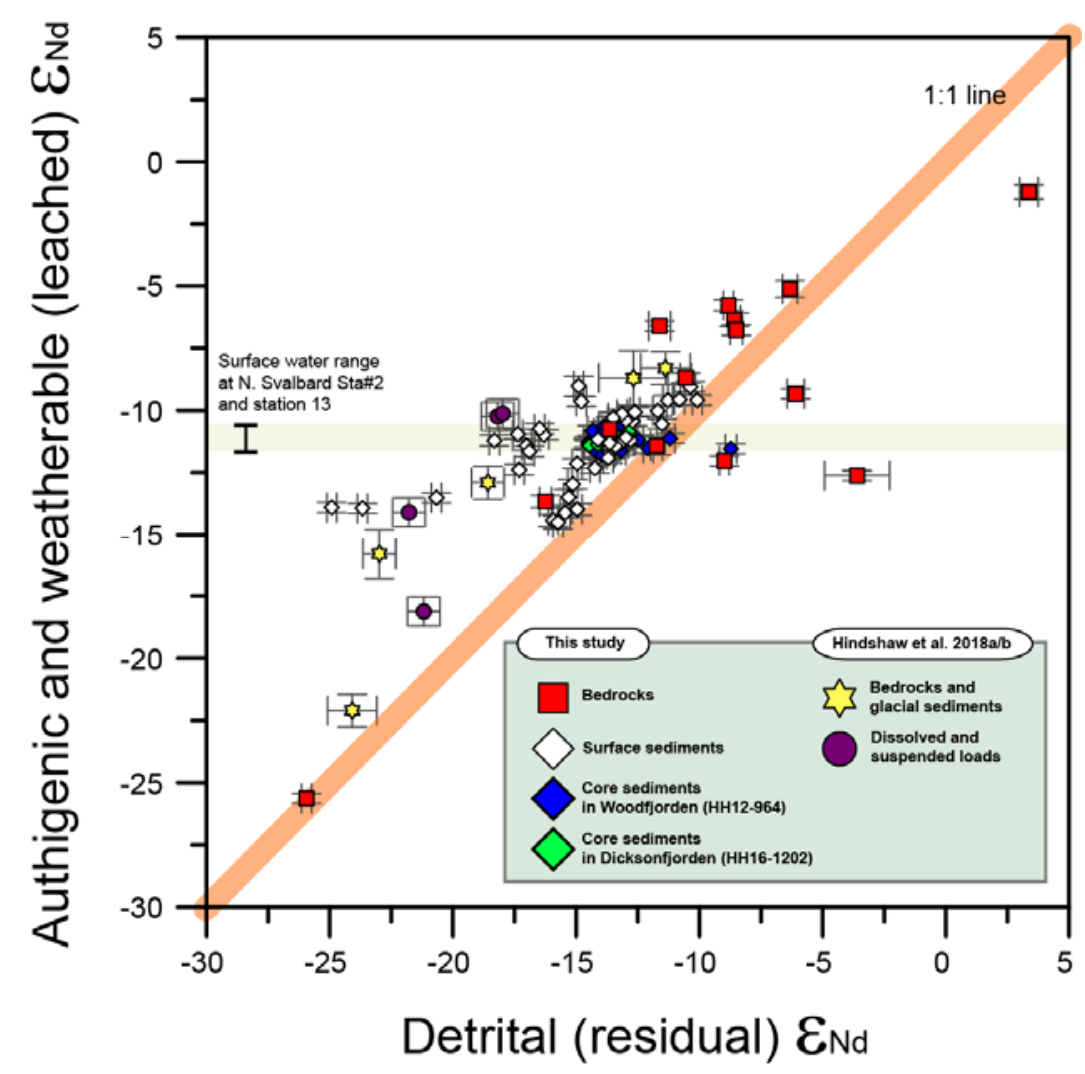

Figure 4. $\varepsilon_{\mathrm{Nd}}$ data comparison between leached (authigenic and weatherable) and residual components (detrital) of the bedrock samples (red squares), surface sediments (white diamonds), core sediments at sites HH12-964 (blue diamonds) and HH16-1202 (green diamonds). For further comparison, the $\varepsilon_{\mathrm{Nd}}$ values of the corresponding components within bedrocks and glacial sediments (yellow stars) and riverine dissolved and suspended loads (purple circles) in Svalbard, as well as seawater range at the Spitsbergen margin (green bar) are also shown (data from Andersson et al., 2008; Hindshaw et al., 2018a; Hindshaw et al., 2018b; Laukert et al., 2017). 


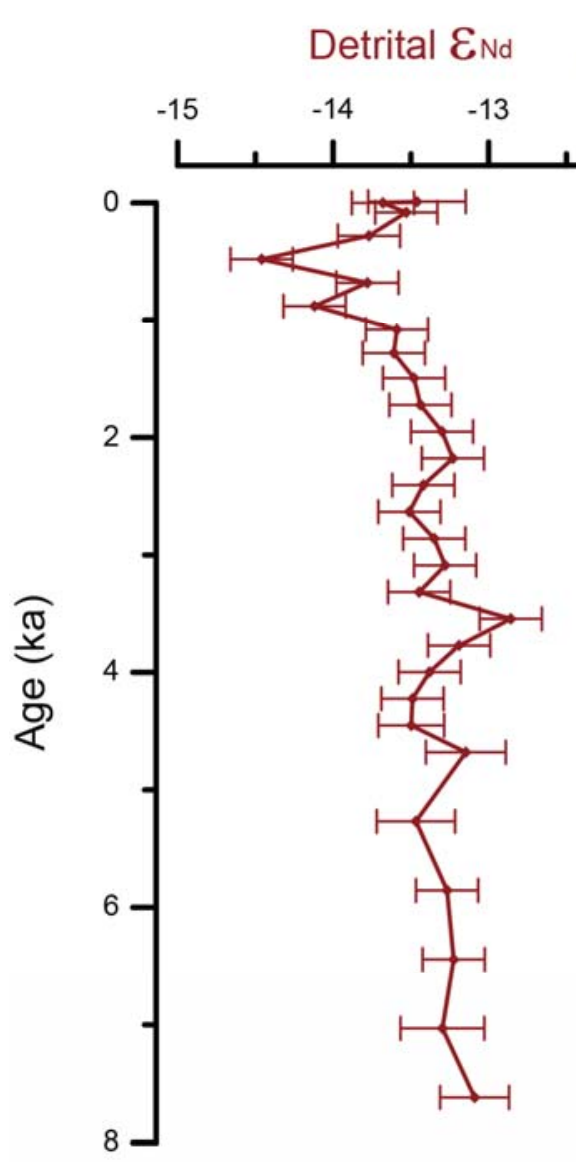

711

712

713

714
Authigenic $\varepsilon_{\mathrm{Nd}}$
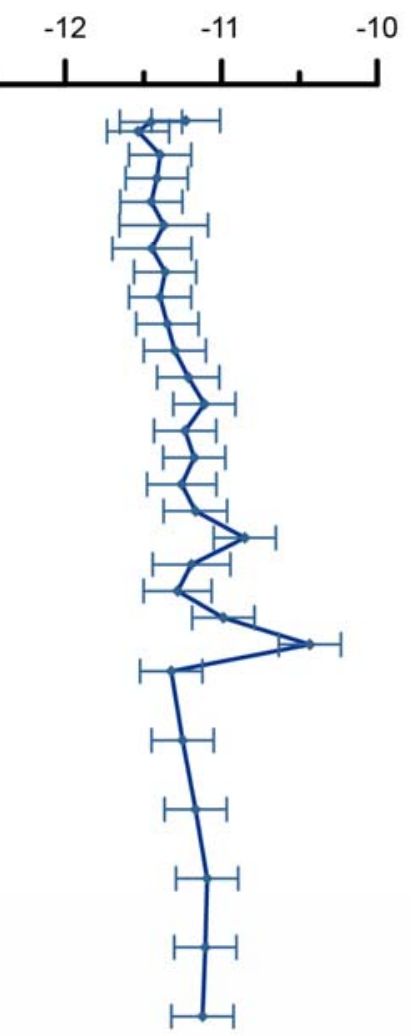

Sed. accum. rate $(\mathrm{cm} / \mathrm{ka})$
IRD flux

(\# of grains $/ \mathrm{cm}^{2} \cdot \mathrm{ka}$ )
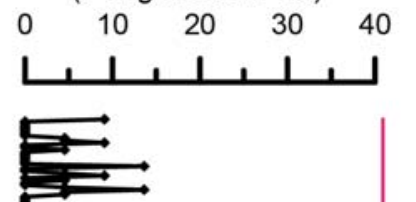

尼

$\sum$
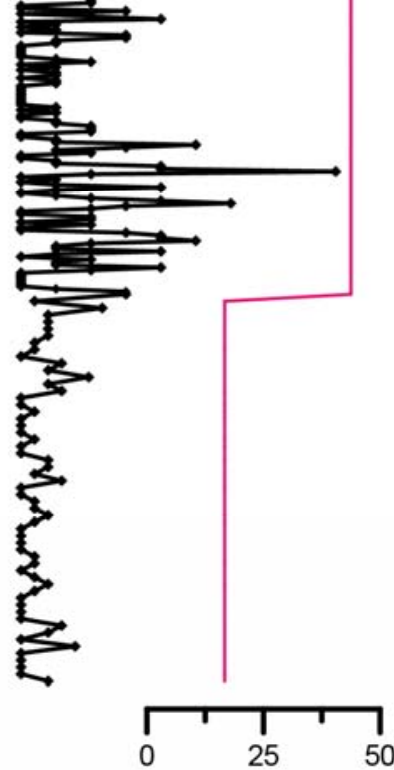

Figure 5. Temporal variation in $\varepsilon_{\mathrm{Nd}}$ values of detrital (red) and authigenic (blue) components at site HH16-1202 in Dicksonfjorden. The $\varepsilon_{\mathrm{Nd}}$ data are compared to the IRD flux (black) and sediment accumulation rate (dark pink) (Joo et al., 2019). Error bars for $\varepsilon_{\mathrm{Nd}}$ represent $\pm 2 \sigma$ uncertainties. 


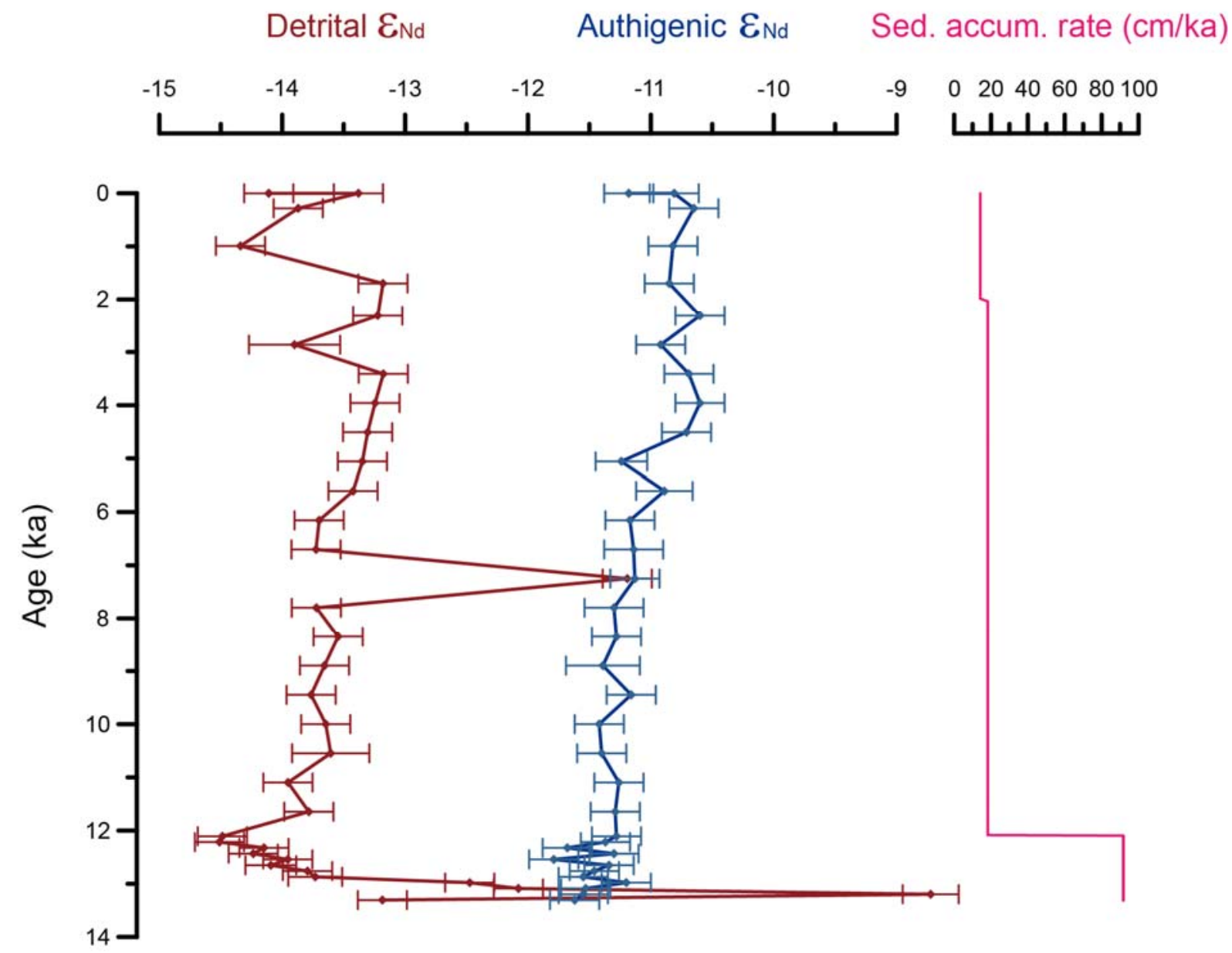

Figure 6. Temporal variation in $\varepsilon_{\mathrm{Nd}}$ values of detrital (red) and authigenic (blue) components at site HH12-964 in Woodfjorden. The $\varepsilon_{\mathrm{Nd}}$ data are compared to the sediment accumulation rate (Hansen, 2014). Error bars for $\varepsilon_{\mathrm{Nd}}$ represent $\pm 2 \sigma$ uncertainties. 


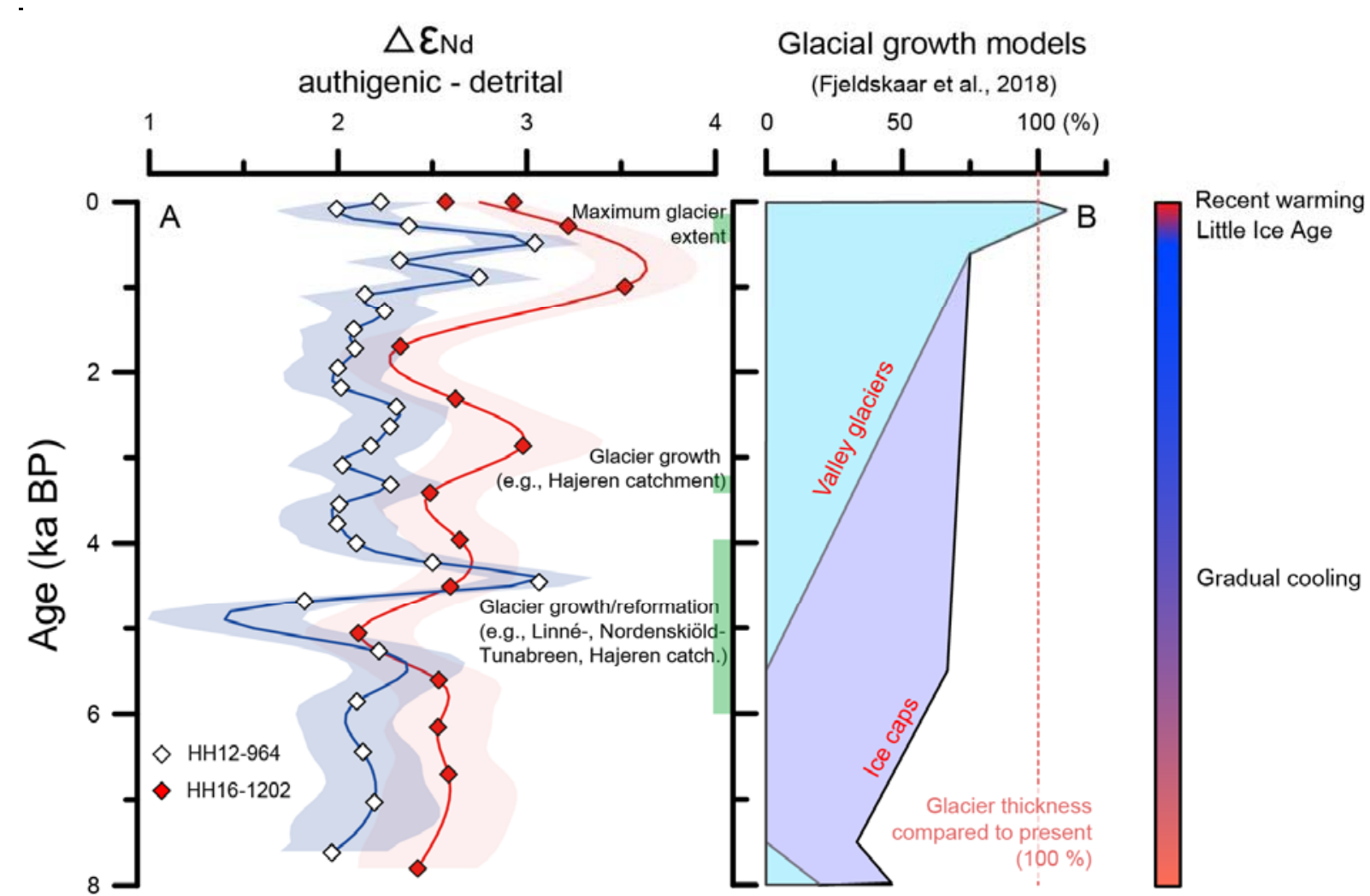

Figure 7. Comparison of (A) the differences between the authigenic and detrital $\varepsilon_{\mathrm{Nd}}$ values $\left(\triangle \varepsilon_{\mathrm{Nd}}\right)$ at core sites HH12-964 (red) and HH16-1202 (blue) and (B) the glacier thickness reconstructed by the best-fit model after Fjeldskaar et al. (2018) over the last $8 \mathrm{ka}$. Higher $\triangle \varepsilon_{\mathrm{Nd}}$ values typically occur during the periods of glacier advances (green bars). Error ranges for $\Delta \varepsilon_{\mathrm{Nd}}$ were calculated based on a smoothing spline Monte-Carlo simulation $(2 \sigma$, resampled at every $0.1 \mathrm{ka}, \mathrm{n}=$ $100,000)$. 
730 Table 1. Detrital and weatherable $\varepsilon_{\mathrm{Nd}}$ values of Svalbard bedrocks.

\begin{tabular}{|c|c|c|c|c|c|c|c|}
\hline $\begin{array}{l}\text { Sample } \\
\text { ID }\end{array}$ & Coordinate & Area & Stratigraphic unit & Age* & $\begin{array}{l}\text { Rock } \\
\text { type }\end{array}$ & $\begin{array}{l}\text { Detrital } \\
\varepsilon_{\mathrm{Nd}}\end{array}$ & $\begin{array}{l}\text { Weatherable } \\
\varepsilon_{N d}\end{array}$ \\
\hline 13071104 & $\begin{array}{l}78.987^{\circ} \mathrm{N} \\
12.087^{\circ} \mathrm{E}\end{array}$ & $\begin{array}{l}\text { Blomstrandhalvøya, } \\
\text { Kongsfjorden }\end{array}$ & $\begin{array}{c}\text { Generalfjella Formation (Fm.), } \\
\text { Krossfjorden Group }\end{array}$ & $\begin{array}{l}\text { Upper } \\
\text { Proterozoic }\end{array}$ & Quartzite & $-8.8 \pm 0.2$ & $-5.8 \pm 0.2$ \\
\hline 13071105 & $\begin{array}{c}78.987^{\circ} \mathrm{N} \\
12.087^{\circ} \mathrm{E}\end{array}$ & $\begin{array}{l}\text { Blomstrandhalvøya, } \\
\text { Kongsfjorden }\end{array}$ & $\begin{array}{l}\text { Generalfjella Fm., } \\
\text { Krossfjorden Group }\end{array}$ & $\begin{array}{c}\text { Upper } \\
\text { Proterozoic }\end{array}$ & Phyllite & $-11.7 \pm 0.3$ & $-11.4 \pm 0.4$ \\
\hline SK01 & $\begin{array}{l}78.545^{\circ} \mathrm{N} \\
16.183^{\circ} \mathrm{E}\end{array}$ & $\begin{array}{l}\text { Skansen, Isfjorden- } \\
\text { Billefjorden }\end{array}$ & $\begin{array}{c}\text { Wood Bay Fm., } \\
\text { Dicksonfjorden Member }\end{array}$ & Devonian & Sandstone & $-8.6 \pm 0.3$ & $-6.4 \pm 0.3$ \\
\hline 080302 & $\begin{array}{l}79.389^{\circ} \mathrm{N} \\
13.622^{\circ} \mathrm{E}\end{array}$ & $\begin{array}{l}\text { Halvdanpiggen, } \\
\text { Woodfjorden }\end{array}$ & Wood Bay Fm. & Devonian & $\begin{array}{c}\text { Red } \\
\text { sandstone }\end{array}$ & $-13.6 \pm 0.3$ & $-10.8 \pm 0.2$ \\
\hline 13071005 & $\begin{array}{l}78.953^{\circ} \mathrm{N} \\
11.758^{\circ} \mathrm{E}\end{array}$ & $\begin{array}{l}\text { Brøggerhalvøya, } \\
\text { Kongsfjorden }\end{array}$ & Brøggertinden Fm. & Carboniferous & $\begin{array}{l}\text { Red } \\
\text { sandstone }\end{array}$ & $-3.6 \pm 1.3$ & $-12.6 \pm 0.2$ \\
\hline SYB05 & $\begin{array}{l}78.944^{\circ} \mathrm{N} \\
11.724^{\circ} \mathrm{E}\end{array}$ & $\begin{array}{l}\text { Brøggerhalvøya, } \\
\text { Kongsfjorden }\end{array}$ & Wordiekammen Fm. & Carboniferous & Limestone & - & - \\
\hline SYB56 & $\begin{array}{l}78.941^{\circ} \mathrm{N} \\
11.703^{\circ} \mathrm{E}\end{array}$ & $\begin{array}{l}\text { Brøggerhalvøya, } \\
\text { Kongsfjorden }\end{array}$ & Wordiekammen Fm. & Carboniferous & Dolostone & - & $-10.9 \pm 0.6$ \\
\hline SK20 & $\begin{array}{l}78.539^{\circ} \mathrm{N} \\
16.159^{\circ} \mathrm{E}\end{array}$ & $\begin{array}{l}\text { Skansen, Isfjorden- } \\
\text { Billefjorden }\end{array}$ & Wordiekammen Fm. & Carboniferous & Dolostone & - & - \\
\hline SYB40.1 & $\begin{array}{c}78.942^{\circ} \mathrm{N} \\
11.704^{\circ} \mathrm{E}\end{array}$ & $\begin{array}{l}\text { Brøggerhalvøya, } \\
\text { Kongsfjorden }\end{array}$ & Wordiekammen Fm. & $\begin{array}{l}\text { Carboniferous - } \\
\quad \text { Permian }\end{array}$ & $\begin{array}{l}\text { Calcareous } \\
\text { shale }\end{array}$ & $-16.3 \pm 0.3$ & $-13.7 \pm 0.3$ \\
\hline SF00.5 & $\begin{array}{l}78.915^{\circ} \mathrm{N} \\
11.654^{\circ} \mathrm{E}\end{array}$ & $\begin{array}{l}\text { Brøggerhalvøya, } \\
\text { Kongsfjorden }\end{array}$ & Kapp Starotin Fm. & Permian & Chert & $-11.6 \pm 0.5$ & $-6.6 \pm 0.2$ \\
\hline 080109 & $\begin{array}{c}78.091^{\circ} \mathrm{N} \\
13.81^{\circ} \mathrm{E}\end{array}$ & $\begin{array}{l}\text { Festningen, } \\
\text { Isfjorden- } \\
\text { Grønfjorden }\end{array}$ & Kapp Starotin Fm. & Permian & $\begin{array}{l}\text { Black } \\
\text { mudstone }\end{array}$ & $-8.5 \pm 0.3$ & $-6.8 \pm 0.2$ \\
\hline $\begin{array}{l}\text { Sval } \\
\text { central }\end{array}$ & $\begin{array}{l}78.545^{\circ} \mathrm{N} \\
16.183^{\circ} \mathrm{E}\end{array}$ & $\begin{array}{l}\text { Skansen, Isfjorden- } \\
\text { Billefjorden }\end{array}$ & Kapp Starotin Fm. & Permian & Anhydrite & - & - \\
\hline $\begin{array}{l}\text { KIGAM } \\
\# 25\end{array}$ & $\begin{array}{l}78.475^{\circ} \mathrm{N} \\
15.812^{\circ} \mathrm{E}\end{array}$ & $\begin{array}{l}\text { Rotundafjellet, } \\
\text { Isfjorden- } \\
\text { Billefjorden } \\
\end{array}$ & Sassendalen Group & $\begin{array}{l}\text { Early - Mid. } \\
\text { Triassic }\end{array}$ & Shale & $-6.1 \pm 0.4$ & $-9.3 \pm 0.2$ \\
\hline 080111 & $\begin{array}{l}78.094^{\circ} \mathrm{N} \\
13.837^{\circ} \mathrm{E}\end{array}$ & $\begin{array}{l}\text { Festningen, } \\
\text { Isfjorden- } \\
\text { Grønfjorden }\end{array}$ & Verdebukta Fm. & Triassic & $\begin{array}{l}\text { Black } \\
\text { mudstone }\end{array}$ & $-10.6 \pm 0.3$ & $-8.7 \pm 0.2$ \\
\hline $\begin{array}{l}20150901- \\
02\end{array}$ & $\begin{array}{l}78.341^{\circ} \mathrm{N} \\
15.857^{\circ} \mathrm{E}\end{array}$ & $\begin{array}{c}\text { Janusfjellet, } \\
\text { Isfjorden- } \\
\text { Adventfjorden }\end{array}$ & $\begin{array}{l}\text { Marhøgda Bed, } \\
\text { Agardhfjellet Fm. }\end{array}$ & Jurassic & $\begin{array}{c}\text { Oolitic } \\
\text { ironstone }\end{array}$ & $-6.3 \pm 0.3$ & $-5.1 \pm 0.3$ \\
\hline $\begin{array}{l}\text { KIGAM } \\
\# 16\end{array}$ & $\begin{array}{c}78.098^{\circ} \mathrm{N} \\
13.913^{\circ} \mathrm{E}\end{array}$ & $\begin{array}{l}\text { Festningen, } \\
\text { Isfjorden- } \\
\text { Grønfjorden }\end{array}$ & Janusfjellet Subgroup & $\begin{array}{c}\text { Mid. Jurassic - } \\
\text { Early } \\
\text { Cretaceous } \\
\end{array}$ & Shale & $3.4 \pm 0.4$ & $-1.2 \pm 0.3$ \\
\hline $\begin{array}{l}\text { KIGAM } \\
\# 5\end{array}$ & $\begin{array}{c}78.239^{\circ} \mathrm{N} \\
15.337^{\circ} \mathrm{E}\end{array}$ & $\begin{array}{c}\text { Platåberget, } \\
\text { Isfjorden- } \\
\text { Adventfjorden }\end{array}$ & Carolinefjellet Fm. & $\begin{array}{c}\text { Early } \\
\text { Cretaceous }\end{array}$ & Shale & $-9.0 \pm 0.2$ & $-12.0 \pm 0.2$ \\
\hline 080114 & $\begin{array}{c}78.099^{\circ} \mathrm{N} \\
13.948^{\circ} \mathrm{E}\end{array}$ & $\begin{array}{l}\text { Festningen, } \\
\text { Isfjorden- } \\
\text { Grønfjorden }\end{array}$ & Helvetiafjellet Fm. & Cretaceous & Sandstone & $-25.9 \pm 0.2$ & $-25.6 \pm 0.2$ \\
\hline
\end{tabular}

